\title{
DETERMINATION OF PEAK DISCHARGE FROM RAINFALL DATA FOR URBANIZED BASINS, WICHITA, KANSAS
}

\section{U.S. GEOLOGICAL SURVEY}

Open-File Report 78-974

Prepared in cooperation with the City of Wichita

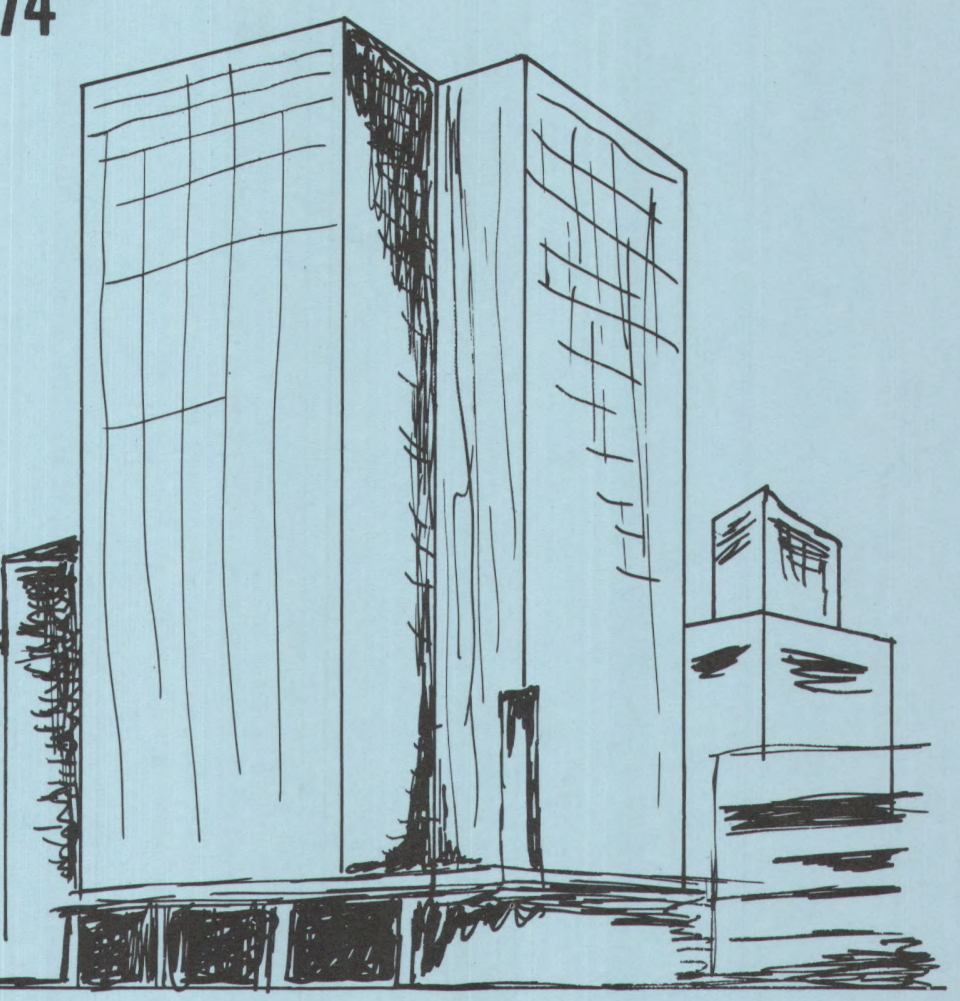



UN ITED STATES

DEPARTMENT OF THE INTERIOR

GEOLOGICAL SURVEY

DETERMINATION OF PEAK DISCHARGE FROM RAINFALL

DATA FOR URBANIZED BASINS,

WICHITA, KANSAS

By C. O. Peek and P. R. Jordan

Open-File Report 78-974

Prepared in cooperation with the

Clty of Wichita

Lawrence, Kansas

October 1978 


\section{CONVERSION TABLE}

The inch-pound units of measurement given in this report are listed in equivalent metric units using the following abbrevlations and conversion factors:

Inch-pound unit

Inch ( In)

foot $(f t)$

mile $(m i)$

square $m i l e\left(m l^{2}\right)$

cublc foot per second $\left(f t^{3} / s\right)$
Multiply by

25.4

.3048

1.609

2.509

.02832
Metric unit

millimeter ( $\mathrm{mm})$

meter ( $\mathrm{m}$ )

kllometer ( $\mathrm{km})$

square kllometer $\left(\mathrm{km}^{2}\right)$

cubic meters per second $\left(\mathrm{m}^{3} / \mathrm{s}\right)$ 


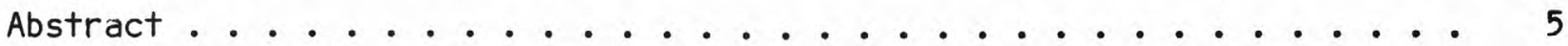

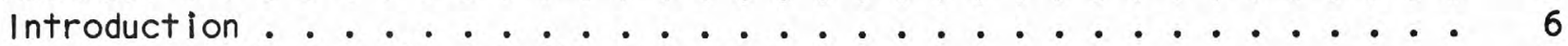

History and description of the data system . . . . . . . . . . 7

Methods of analysis ................... . . . 12

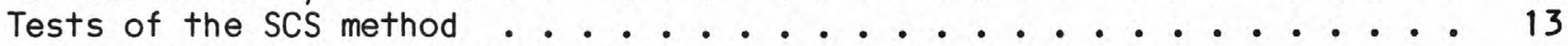

Application of modified SCS method to ungaged basins . . . . . . . 15

Probability, recurrence interval, and the "design storm" concept . . 15

Calculation of synthetic hydrograph ............. 17

Sample computation ................. 22

Shortcut calculation .................... 26

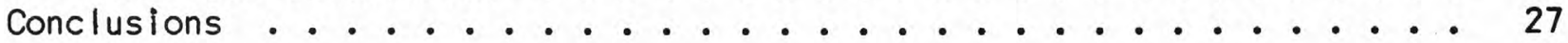

References ........................... . . . . . 28

Appendix: Rainfall and discharge data for selected storms . . . . . . 31

\section{ILLUSTRATIONS}

Figure

Page

1. Map showing location of report area, selected drainage basins, and data-collection sites ............. . 8

2. Graph showing normal and observed 3-hour rainfall frequencies in the Wichita area .............. 13

3. Graph showing accumulation of rainfall to 24 hours for continental United States .............. 16

4. Graph showing 24-hour rainfall frequency for the Wichita area ............................ 17

5. Map showing soll classification according to infiltration capacity ................................... 18

6. Graph showing relationship of runoff to rainfall and curve number. . . . . . . . . . . . . . . . 20

7. Trlangular hydrograph relationships . . . . . . . . . . 20

8. Triangular hydrographs and synthetic hydrograph resulting from 100-year storm on hypothetical urbanized basin.................... 


\section{TABLES}

Table

1. Streamflow-gaging stations and perlods of record . . . . . . . 9

2. Characteristics of streams studied in and near Wichita . . . . . . . . . . . . . . . . 10

3. Comparison of results of triangular-hydrograph computations for largest events . . . . . . . . . . . . . 14

4. Runoff curve numbers for selected agricultural, suburban, and urban land use ................ . . . 19

5. Rainfall accumulation and triangular-hydrograph ordinates for 100-year storm ................. 24

6. Calculation of $\Delta \mathrm{q}$ for seven increments .............. 27 


\section{DETERMI NATION OF PEAK DISCHARGE FROM RAINFALL}

DATA FOR URBANIZED BASINS, WICHITA, KANSAS

C. O. Peek and P. R. Jordan

\section{ABSTRACT}

Rainfall and runoff data from urbanized drainage basins in the Wichlta area, Kansas, were used to evaluate the Soll Conservation Service synthetichydrograph method of computing flood hydrographs from rainfall data. The method was tested on six basins where the impervious surface ranged from 11 percent on the least urbanized basin to 40 percent on the most urbanized. Twenty-two of the largest storm events for whlch peak discharges had been observed were used in the test. After modification of the method for this particular area, results showed an average error of 20 percent, disregarding sign, with an apparent blas of 8 percent. However, uncertainties in some of the data make it impractical to adjust for bias.

Application of the modifled method using data on rainfall, impervious surface, solls, land use, channel slope, length of main channel, and drainage area is described for a hypothetical basin. As an alternative to more complete and complex modeling by digital computer, a peak discharge for dralnage design can be calculated by applying the SCS method to a standardized "design storm" for a speclfied recurrence interval. The method is sensitive to soll conditions and land use; therefore, accurate information on these factors is necessary. 
Wichita, Kansas, located in the south-central part of the State, continues to grow as other industry moves in to supplement its alrcraft industry. This growth is causing increased urbanization and changes in the storm drainage. The purpose of this study is to provide peak discharges from rainfall data in small basins with varying degrees of urbanization. The peak discharges are needed for design of storm sewers, bridges, channel improvements, and for related purposes.

Wichita has had many floods in years past; the extent of the largest floods was reported by Ellis and others (1963). The clty, which is located at the junction of the Lit+le Arkansas and the Arkansas Rivers, experlenced sIgnificant flooding within the corporate limits prior to the construction of the Wichita-Valley Center Floodway System, completed in the late 1950's. Other flood control and channel Improvement work was performed on Chisholm Creek, Gypsum Creek, and Dry Creek. The Wichlta-Valley Center Floodway System and other improvements have greatly decreased flooding from the major streams.

The continuing growth and development in the Wichlta area produce significant changes in the hydrology of the small streams. As urbanization progresses, more of the area is covered with impervious surface in the form of rooftops, paved streets, paved parking lots, etc., and the quantity of runoff increases significantly from a given amount of rainfall. Heavy rainfall on impervious surfaces, coupled with the use of storm sewers, decreases the time interval between the beginning of rainfall excess and the accompanying rise in the stream channel draining the basin. As increased runoff from different parts of the basin arrives in the stream channel simultaneously, the basin's response time is shortened and higher peak discharges occur.

Anderson (1970) found that, in northern Virginla, a completely impervious surface increased the average flood-peak discharge by a factor of $21 / 2$. However, an impervious surface had less effect on floods larger than the average and had an insignificant effect on the 100-year flood. Johnson and Sayre (1973) found that, In Houston, Texas, a change from a rural basin to a fully urbanized basin increased the magnitude of the 50-year flood about five times. Espey and others (1965) found that, in Austin, Texas, urbanization in a watershed produces floods with peak discharges from 100 to 300 percent greater than on an undeveloped watershed. Dempster (1974) found a much smaller effect of urbanization in Dallas than in the Austin, Texas study. The disparity of results indicates the need for basic data to define the hydrologic condltions in a particular geographlc area of interest. For this reason, data have been collected at Wichlta since 1964 to provide direct knowledge of the local hydrologic conditions. Through a cooperative agreement, Wichita city hydrographers and techniclans accomplished nearly all the data collection.

The continuing spread of urban development in the Wichita area carries with it the problem of optimum design of storm sewers and drainage channels. Existing techniques for computation of design flows have been developed for such clities as Boston and Houston, but the techniques are not necessarily directly applicable to Wichita. In recent years numerous rainfall-runoff models have been developed for calculation by digital computer. Digital modeling will be the preferred technique when adequate data have been obtained for verification and adaptation of such a model for the Wichita area. For the present time, however, simpler methods must be chosen. 
Data collection began in 1964 at seven partlal-record streamflow-gaging stations and rainfall recorders (James, 1967). The locations of these and subsequent stations are shown in figure 1 and IIsted, along with the perlods of record, in table 1. The Dry Creek basin above Lincoln Street was extensively urbanized in 1964, and Gypsum Creek above Gilbert Street was thought to be developing rapidly. Chisholm Creek basin and Middle Fork ChIsholm Creek basin were expected to develop rapldly. Big Slough was thought to be in a potential Industrlal area. West Branch of Chisholm Creek and Spring Creek were expected to remain essentlally rural.

Data were being collected on three additional basins by 1970. The additional basins were Calfskin Tributary to Cowskin Creek at Clearwater Road, Westlink Tributary at Westfield Avenue, and Gypsum Creek at Oliver Street. The Calfskin Trlbutary basin was rural whlle Westlink Trlbutary at Westfleld Avenue and Gypsum Creek at Oliver Street were partially urbanized and developing.

As recommended by Richards (written commun., 1971), gaging was begun in 1971 on two additional urbanized basins, Dry Creek at Pawnee Avenue and Fabrique Branch of Gypsum Creek at Harry Street. At this time, gaging was discontinued on three rural basins that indicated $11+t+l e$ tendency to become urbanized. The stations discontinued were West Branch of Chisholm Creek at 61 st Street, Middle Fork of Chisholm Creek at 45th Street, and Big Slough at Ridge Road. These changes left nine basins where data were being collected.

The three most urbanized basins were Dry Creek above Lincoln Street, Dry Creek above Pawnee Avenue, and Fabrique Branch of Gypsum Creek above Harry Street. Because of the relatively short rainfall-runoff response times in these basins, it was necessary to install dual-digital recorders for rainfall and stream stage. The rainfall and stage recorders operated from a single timer, which recorded at 5-minute intervals. Operating both digital recorders from a single timer is advantageous in eliminating time discrepancles between rainfall and stream stage, but it necessitates the location of the two gages at the same site. Therefore, the rainfall is recorded only at the lower end of the basin.

In each of the rural and partially urbanized basins, equipment was installed that included a rain gage, which recorded at 15-minute intervals, near the center of the basin, and a continuous graphic recorder for stream stage at the lower end of the basin. This system was satisfactory because the basin response times were relatively long and time errors were not critical. Several nonrecording rain gages, monitored by local observers, also were installed in all basins. The rainfall reported at the non-recording gages showed that the amounts recorded at the recording gages were representative of the rainfall over their respective basins. The properties of the individual basins are shown in table 2. 


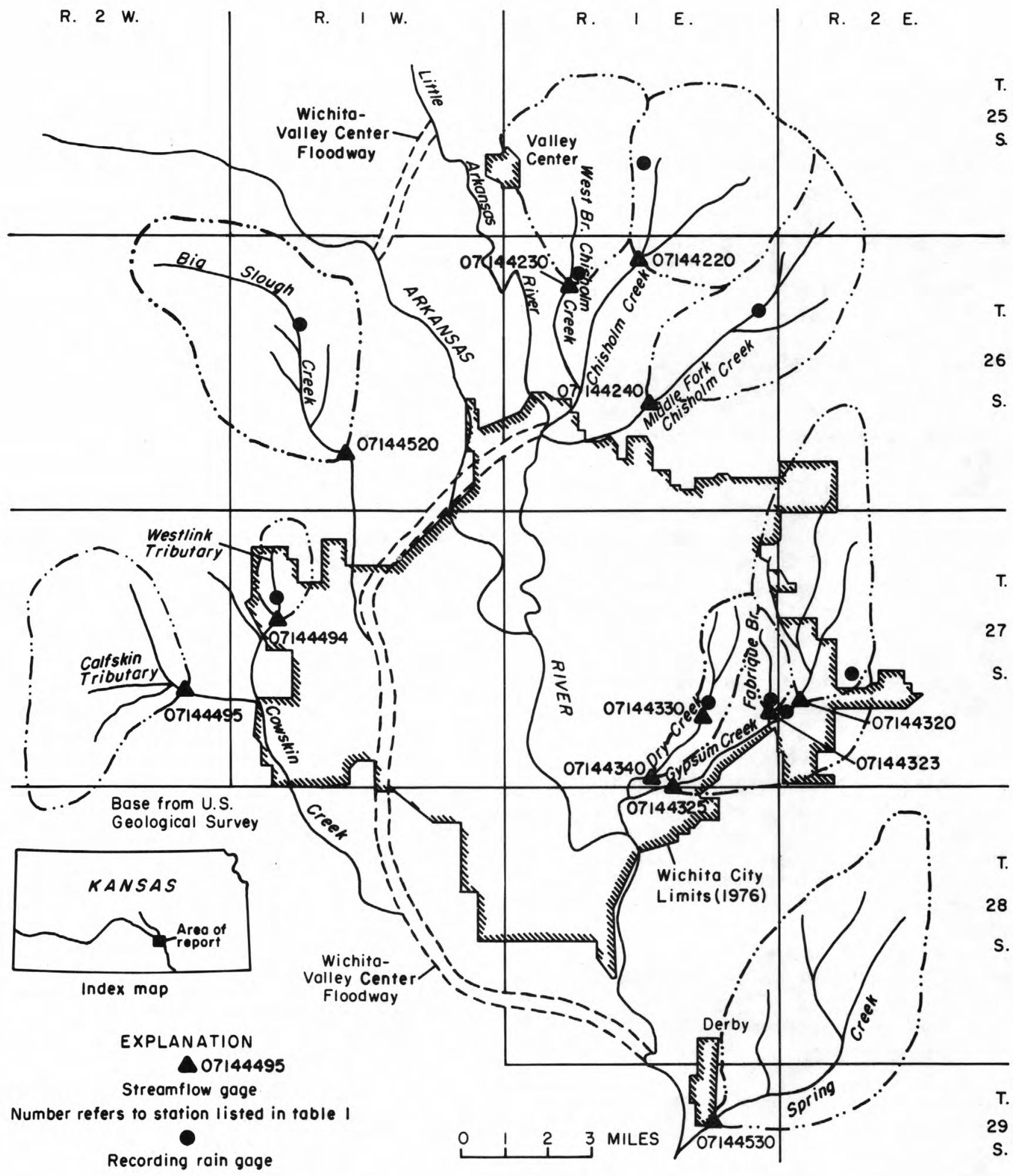

Basin boundary

Figure 1.--Location of report area, selected drainage basins, and data-collectlon sites. 
Table 1.--Streamflow-gaging stations and perlods of record.

Station

identification

number

Station name

Perlod of record

07144220

Chisholm Creek at 69th Street

3-64 to present

07144230

West Branch Chisholm Creek at 61 st Street

07144240

Middle Fork Chisholm Creek at 45th Street

3-64 to $1-71$

$3-64$ to $1-71$

07144320

Gypsum Creek at Gllbert Street

3-64 to present

07144323

Fabrique Branch of Gypsum Creek

3-71 to present at Harry Street

07144325

Gypsum Creek at Ollver Street

3-68 to present

07144330

Dry Creek at Lincoln Street

3-64 to present

07144340

Dry Creek at Pawnee Avenue

3-71 to present

07144494

West Ilink Trlbutary at Westfleld Avenue

3-68 to present

07144495

Calfskin Creek Trlbutary at Clearwater Road*

10-67 to present

07144520

Big Slough at Ridge Road

3-64 to 1-71

07144530

Spring Creek at Woodlawn Avenue**

10-64 to present

* No precipitation data since 10-70.

** Stage gage only.

Most of the stage gages for this study were not installed to monitor low flow but only medium-and high-flow stages. The stage-discharge relations were established by current-meter measurements because limited funding did not permit the extensive surveys and computations needed for indirect measurements. Most of the stage-discharge rating curves were only of fair accuracy owing to an insufficient number of discharge measurements, particularly at high discharges. Dry Creek at Pawnee Avenue and Fabrique Branch of Gypsum Creek at Harry Street had the least rellable rating curves because of the short perlod of record and the necessity of extending the rating curve. 
Table 2.--Characterlstics of streams studled in and near Wichita.

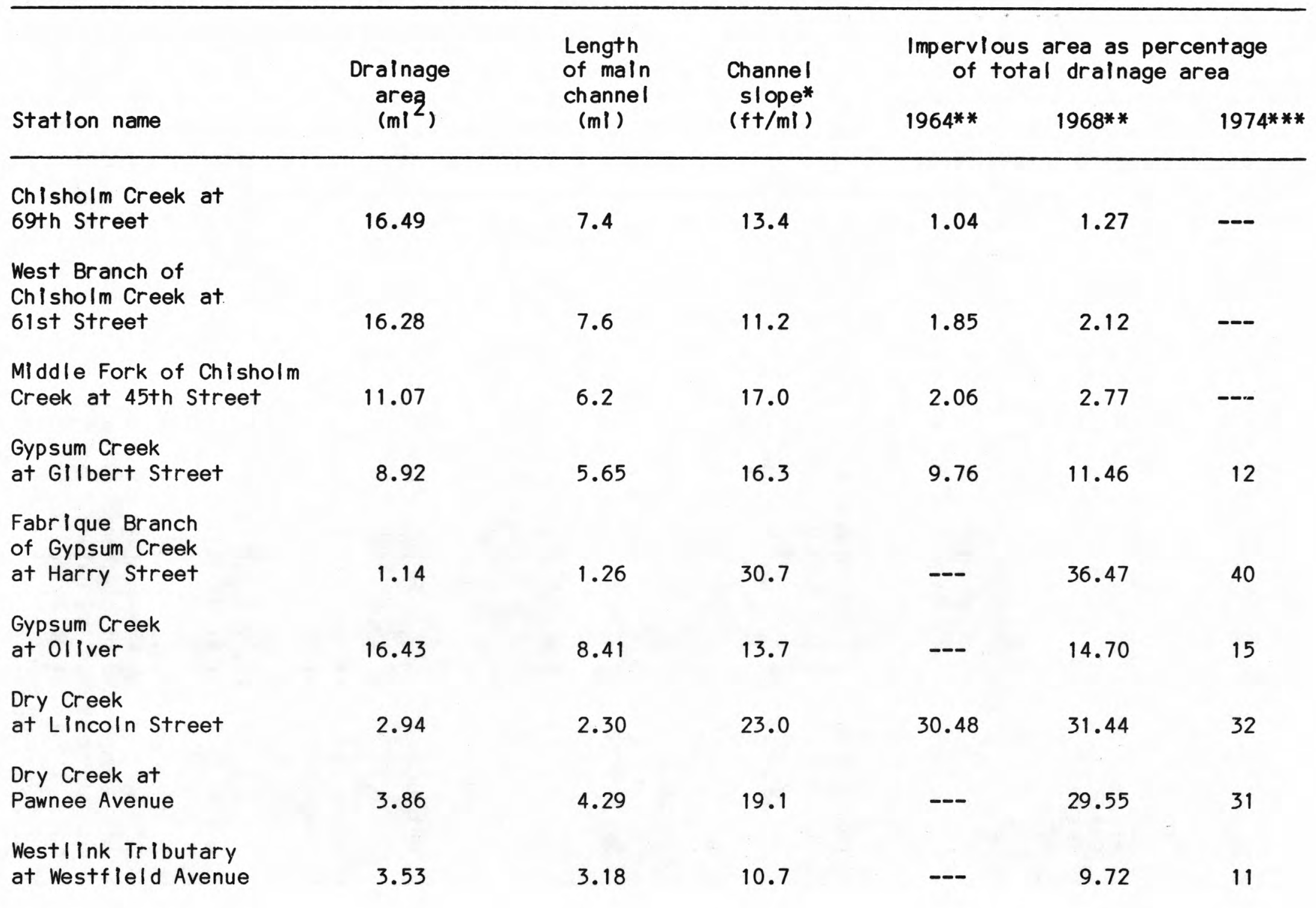


Table 2.--Characteristics of streams studied in and near Wichita (concluded).

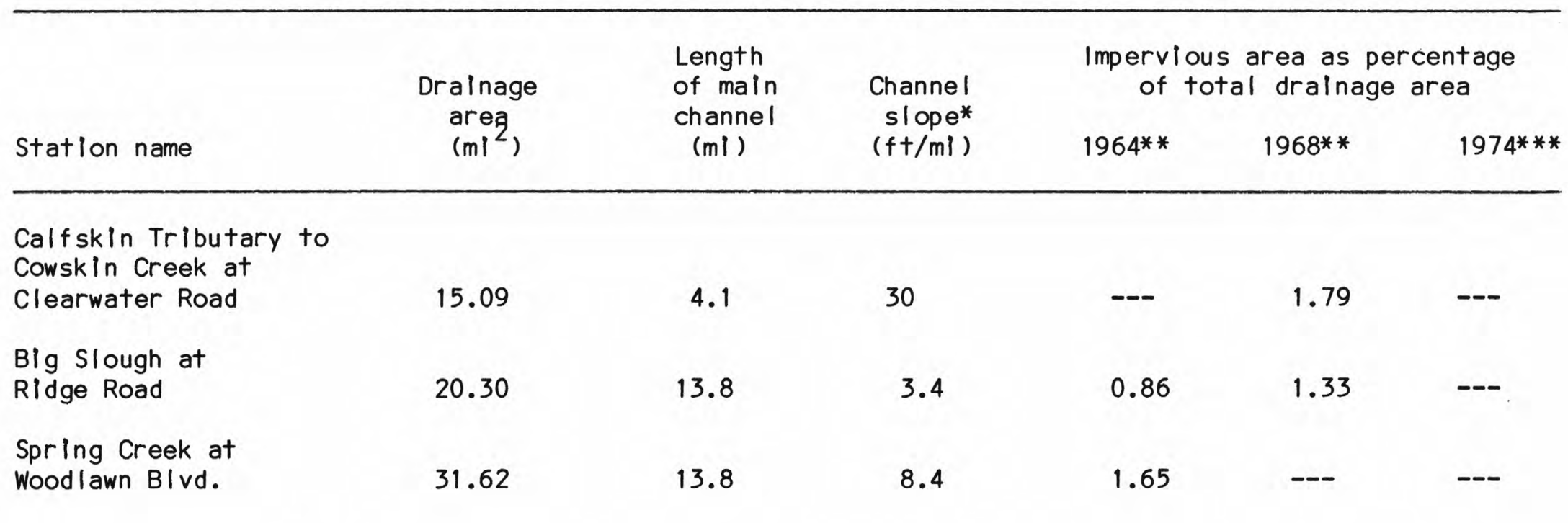

* Ratio of elevation difference to horizontal distance between points at 10 percent and 85 percent of channel length.

** Furnished by Wichita City-County Flood Control office.

*** Estimated from aerlal photos. 
Previous investigators have used varlous methods of analysis to determine the effect of urbanization on high flows or to provide a method of calculating flood-frequency curves for urbanized areas. The initial method of analysis in the Wichita area was to continue gaging several streams as their drainage basins changed from mostly rural to mostly urban and to use these data in identifying the effects of urbanization on the unit hydrographs. During the data-collection phase of the project, however, the urbanization did not proceed as expected. Few of the data reflected conditions approprlate for use of the intended approach (James, 1967; Richards, written commun, 1971). Thus, the circumstances forced the consideration of alternate methods of analysis.

The alternate methods considered can be described generally as those that use (1) frequency analysis of observed peak-flow data, (2) detalled modeling of the runoff process, and (3) synthetic unit hydrographs.

Frequency analysls of observed peak-flow data has been used successfully for rural basins (Dalrymple, 1960; Jordan and Irza, 1975) where falrly long records of peak flows are avallable. Application of this method to the wichita area is precluded partly by the short length of flow records avallable, but mainly because the avallable record represents a perlod of smaller-than-normal intense rainfall events. Figure 2 shows the deficlency of intense rainfall during 1964-76, represented by data from the Gilbert Street station, as compared with the normal (based on Herschfleld, 1961) expected over a long perlod.

In recent years, with the avallabillty of high-speed digital computers, most research efforts in analysis of urban runoff have been directed to detalled modeling of the runoff process. Much success has been achleved in digital modeling, but the method involves stringent requirements for data: continulty, format, and machine-readablility. Data collection for this project, which began when digital modeling was in its infancy, was not designed to meet these stringent requirements. Some changes have been made in instrumentation so that, at some time in the future, callibration of a digital model may be feasible for the Wichita area. At the present time, however, application of digital modeling is impractical for the Wichita data.

Several "synthetic unit-hydrograph" methods have been developed for urban basins, but most are somewhat complex for use in routine drainage design. One method, which was developed by the U.S. Soll Conservation Service (1964; 1975; Kent, 1973), appears reasonably simple to apply, covers the essential hydrologic and hydraulic considerations, and adapts to all degrees of urbanization. Preliminary tests indicated that good results could be obtained by this method using Wichita data with simple modifications. Thus, the Soll Conservation Service (hereafter abbreviated SCS) method was tested further. 


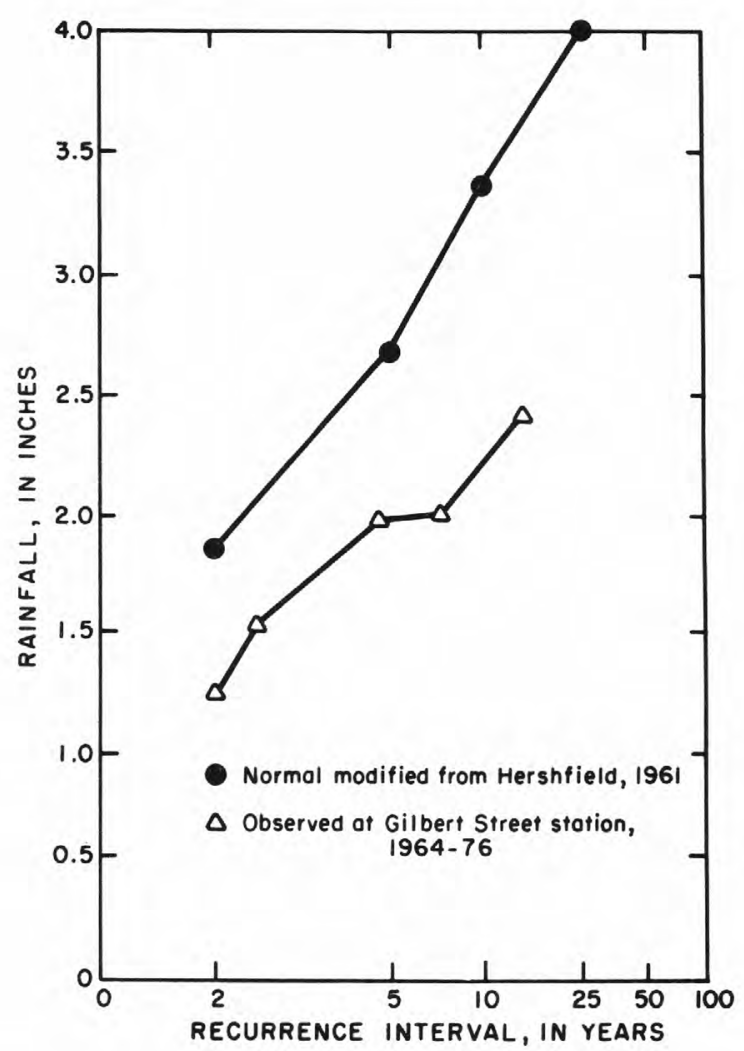

Figure 2.--Normal and observed 3-hour rainfall frequencles in the Wich ita area.

TESTS OF THE SCS METHOD

The SCS hydrograph method uses a relation of runoff to rainfall and sollcover characteristics to calculate the runoff for short time increments, then distrlbutes each runoff increment in a trlangular discharge hydrograph. The base and peak times of the hydrograph are related to characteristics of the drainage basin. Finally, the triangular hydrograph ordinates are summed to form the resulting synthetichydrograph. Detalls of the method are given later in this report with a numerical example.

The calculated time distribution of discharge is governed by the lag time, which is defined by the SCS (Kent, 1973) as the time from the centroid of rainfall excess to the discharge peak. During the testing by application of the SCS method to actual rainfall events, the calculated lag times consistently exceeded the observed lag times. Examination of alternate methods of calculating lag times showed that an equation proposed by Putnam (1972) gave good results. Thus the SCS hydrograph method was modifled by adopting Putnam's equation for lag time.

The modifled SCS triangular-hydrograph method was tested for large rainfall events, and the resulting synthetic peak discharges were compared with observed discharges, as shown in table 3. 
Table 3.--Comparison of results of trlangular-hydrograph computations for largest events.

\begin{tabular}{|c|c|c|c|c|}
\hline Station & Date & $\begin{array}{l}\text { Observed } \\
\text { peak } 3 \text { low } \\
\mathrm{ft} / \mathrm{s}\end{array}$ & $\begin{array}{c}\text { Synthet ic } \\
\text { peak } \text { flow }_{\mathrm{ft} / \mathrm{s}}\end{array}$ & $\begin{array}{l}\text { Percent } \\
\text { error } \\
\end{array}$ \\
\hline $\begin{array}{l}\text { Gypsum Creek } \\
\text { at Gllbert Street }\end{array}$ & $\begin{array}{l}\text { June } 11,12,1970 \\
\text { May } 28,1975 \\
\text { June } 2,3,1975 \\
\text { June } 16,17,1975\end{array}$ & $\begin{array}{l}1450 \\
1300 \\
1250 \\
1060\end{array}$ & $\begin{array}{l}1420 \\
1830 \\
1035 \\
1060\end{array}$ & $\begin{array}{l}-2 \\
+41 \\
-17 \\
0\end{array}$ \\
\hline $\begin{array}{l}\text { Fabrique Branch } \\
\text { of Gypsum Creek } \\
\text { at Harry Street }\end{array}$ & $\begin{array}{l}\text { July } 14,1973 \\
\text { May 28, } 1975 \\
\text { June 2, 3, } 1975 \\
\text { June } 17,1976\end{array}$ & $\begin{array}{r}860 \\
1150 \\
830 \\
820\end{array}$ & $\begin{array}{l}770 \\
630 \\
900 \\
393\end{array}$ & $\begin{array}{l}-10 \\
-45 \\
+8 \\
-52\end{array}$ \\
\hline $\begin{array}{l}\text { Gypsum Creek } \\
\text { at Oliver Street }\end{array}$ & $\begin{array}{l}\text { April } 20,21,1974 \\
\text { May } 9,1974 \\
\text { May 13, 14, } 1974 \\
\text { June } 16,17,1975\end{array}$ & $\begin{array}{r}1550 \\
1020 \\
870 \\
1540\end{array}$ & $\begin{array}{r}1845 \\
905 \\
895 \\
1450\end{array}$ & $\begin{array}{l}+19 \\
-11 \\
+3 \\
-6\end{array}$ \\
\hline $\begin{array}{l}\text { Dry Creek } \\
\text { at Lincoln Street }\end{array}$ & $\begin{array}{l}\text { May } 27,1964 \\
\text { June } 4,5,1965 \\
\text { May } 28,1975 \\
\text { June } 16,17,1975\end{array}$ & $\begin{array}{r}1100 \\
1170 \\
960 \\
1270\end{array}$ & $\begin{array}{l}1330 \\
1760 \\
1240 \\
1040\end{array}$ & $\begin{array}{l}-21 \\
+50 \\
+29 \\
-18\end{array}$ \\
\hline $\begin{array}{l}\text { Dry Creek } \\
\text { at Pawnee Avenue }\end{array}$ & $\begin{array}{l}\text { July } 27,28,1971 \\
\text { June } 16,1975 \\
\text { July } 3,1976\end{array}$ & $\begin{array}{r}520 \\
1600 \\
740\end{array}$ & $\begin{array}{r}555 \\
1690 \\
674\end{array}$ & $\begin{array}{l}+7 \\
+6 \\
-9\end{array}$ \\
\hline $\begin{array}{l}\text { Westlink Tributary } \\
\text { at Westfield Avenue }\end{array}$ & $\begin{array}{l}\text { June } 21,1969 \\
\text { October } 23,1970 \\
\text { June } 23,1976\end{array}$ & $\begin{array}{l}355 \\
640 \\
195\end{array}$ & $\begin{array}{l}196 \\
672 \\
144\end{array}$ & $\begin{array}{l}-44 \\
+5 \\
-26\end{array}$ \\
\hline
\end{tabular}

The average error of 20 percent, disregarding sign, shows that the estimates are reasonably accurate. The geometric mean of the ratios of synthetic to observed peak flows is 0.92 , showing an apparent blas of 8 percent. No ad justment for bias is proposed here because the runoff events avallable for testing do not include extremely large events and because some of the apparent bias may result from inaccurate data of "observed" discharges. The results on Fabrique Branch of Gypsum Creek at Harry Street show the largest errors, but the station has a poor stage-discharge rating curve owing to a lack of large discharge measurements. Dry Creek at Pawnee Avenue also has a poor rating for the same reason, and malfunction of equipment prevented evaluation of several large events.

The results of the testing suggest that the triangular-hydrograph method provides reasonable estimates of actual events. It is assumed that the method will provide reasonable results when applied to the calculation of design flows for ungaged basins. However, continued data collection and additional flood measurements are needed elther to verify the method or to provide the basis for further modifications. 


\section{APPLICATION OF MODIFIED SCS METHOD TO UNGAGED BASINS}

The SCS triangular-hydrograph method of estimating peak runoff discharges for small ungaged watersheds, as outIIned by U.S. Soll Conservation Service (1964) and Kent (1973) was originally designed for rural basins. The urban hydrology report by U.S. Soil Conservation Service (1975) states that the trlangularhydrograph method should be used only on basins with drainage areas of 2,000 acres $\left(3.1 \mathrm{mi}^{2}\right)$ or less. The study in the wichita area found results were reasonable even when used on basins as large as $16 \mathrm{mi}^{2}$. The same SCS report states that results would be suspect if slopes are greater than 30 percent; none of the slopes in the Wichita area approach this limit.

\section{Probabillty, Recurrence Interval, and the "Design Storm" Concept}

For purposes of hydrologic analysis and for some economic design purposes, the degree of extremity of a flood is expressed by its "probability of exceedance." A very low probablility indicates an extreme flood. A flood that has a probabllity of 2 percent has a 2-percent chance of being exceeded in any one year.

Although the concept of probability is the most meaningful way of classifying and comparing floods, the terminology in more common use is the "recurrence interval" in years, which is 100 times the reciprocal of the probability of exceedance when the probability is in percent. Thus, a 2-percent probability flood has a recurrence interval of 50 years. Stated in more general terms, a flood having a recurrence interval of $N$ years is expected to be exceeded an average of once in each perlod of $\mathrm{N}$ years and is known as the "N-year flood." More than one flood exceeding that magnitude may occur in any particular period of $\mathrm{N}$ years, or no flood exceeding that magnitude may occur during an equivalent perlod. The fact that a flood of given magnitude occurs in one year does not reduce the probabllity of a flood of equal or greater magnitude occuring during the next year. The term "recurrence interval" will be used in this report instead of probability.

For ungaged small basins, the preferred method (Alley, 1977, p. 9) of determining peak flows for specifled recurrence intervals is to use a digital-computer model to create several decades of synthetic record of high flows. A recurrenceinterval analysis would then be made for the serles of annual peak discharges. Until several digital-computer models have been tested with data from wichiua and a model selected and adapted for convenient use, a peak discharge for drainage design can be calculated by applying the SCS method to a standardized "design storm". Application of the SCS method to the estimation of flood-frequency discharges depends on the assumption of equality between rainfall recurrence interval and discharge recurrence interval. A rainfall event -- the "design storm" -- having a given recurrence interval is assumed to produce a discharge peak having the same recurrence interval. It has been shown by several investigators (Mawson, 1959; Wilson, 1968; Wasson, 1969) that this assumption is not generally correct in rural areas. The antecedent moisture conditions (wetness of the soll and temporary surface storage) in rural areas may be widely different before each storm. The result is that a 5-year recurrence interval storm on a dry basin may produce 2-year recurrence interval discharge peak; whereas, the same storm on a wet basin may produce a 10-year recurrence interval discharge peak. 
In drainage design and flood-hazard studies of urban areas, the problems prevlously described are much less severe than for rural areas. A heavy storm on an imprevious urban area will produce a significant peak discharge even if the area was previously dry; antecedent molsture conditions have little effect on the amount of runoff from Impervlous areas; and antecedent conditions on pervious urban areas are more uniform because of lawn watering. Thus, a peak flow calculated by the synthetic-hydrograph method should have approximately the same recurrence interval as the rainfall from which it was calculated if an average antecedent moisture condition is used in the calculation.

In the future, digltal-computer models will be avallable for calculations of hydrographs resulting from several storms each year for a large number of years, by the SCS method or other methods. Computer models available at the present time have not been tested for application to the Wichlta data and the requirements are unduly complex for application to routine design calculations. The modified SCS method presented here is simple, easily applied, and should give good results when applied to urbanized basins in and near Wichita.

The average accumulation of rainfall for 24 hours in heavy storms occurring in the United States, as given by Kent (1973), is shown in figure 3. The terms used in figure 3 are defined as follows: $P_{x}$ is accumulated rainfall, in inches, for $x$ hours, and $\mathrm{P}_{24}$ is total rainfali, in inches, for 24 hours. The rainfali accumulation from figure 3 can be used with the 24-hour rainfall for a selected recurrence interval from figure 4 to produce a "design storm" from which a discharge hydrograph can be calculated.

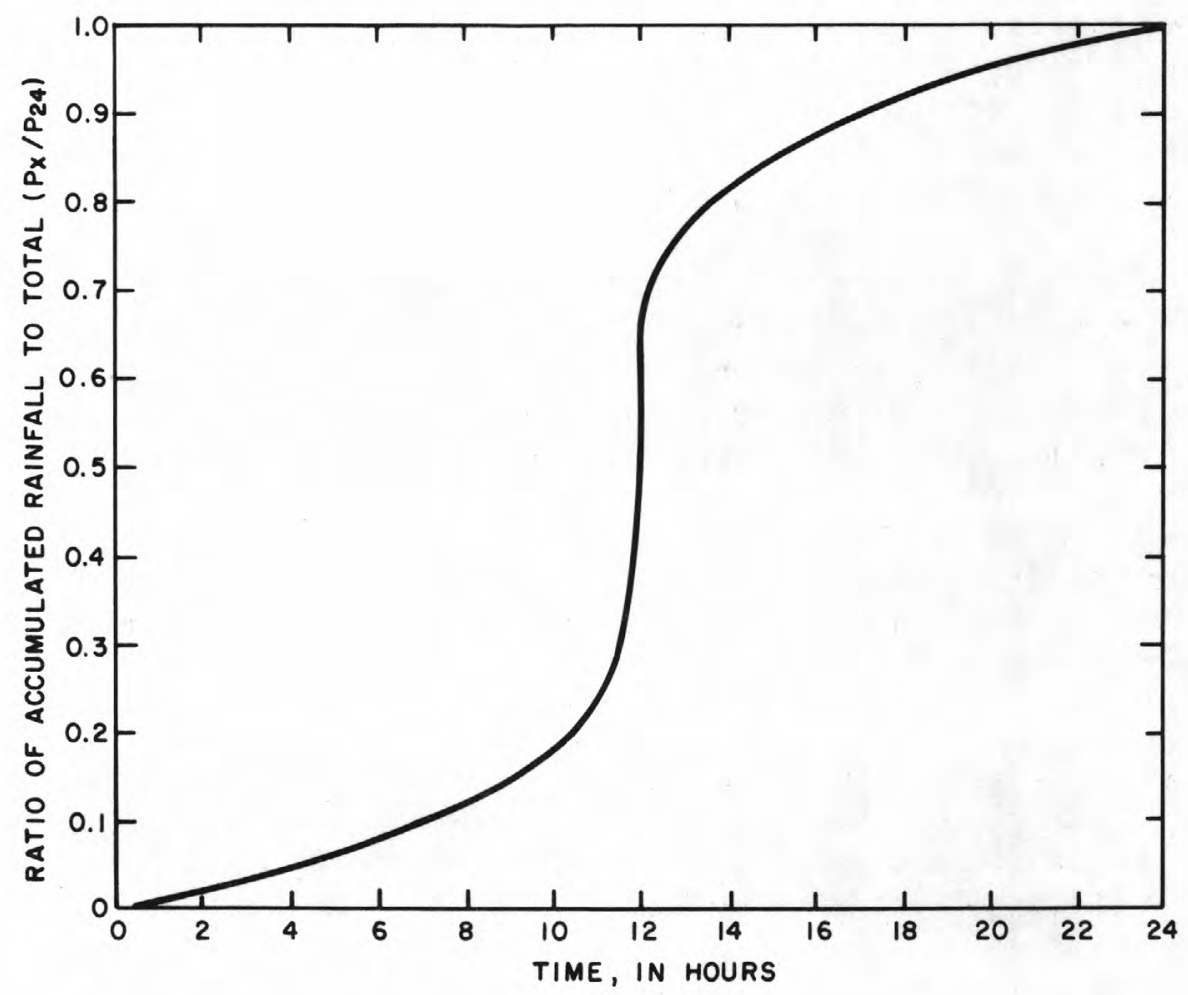

Figure 3.--Accumlation of rainfall to 24 hours for continental United States (Kent, 1973). 


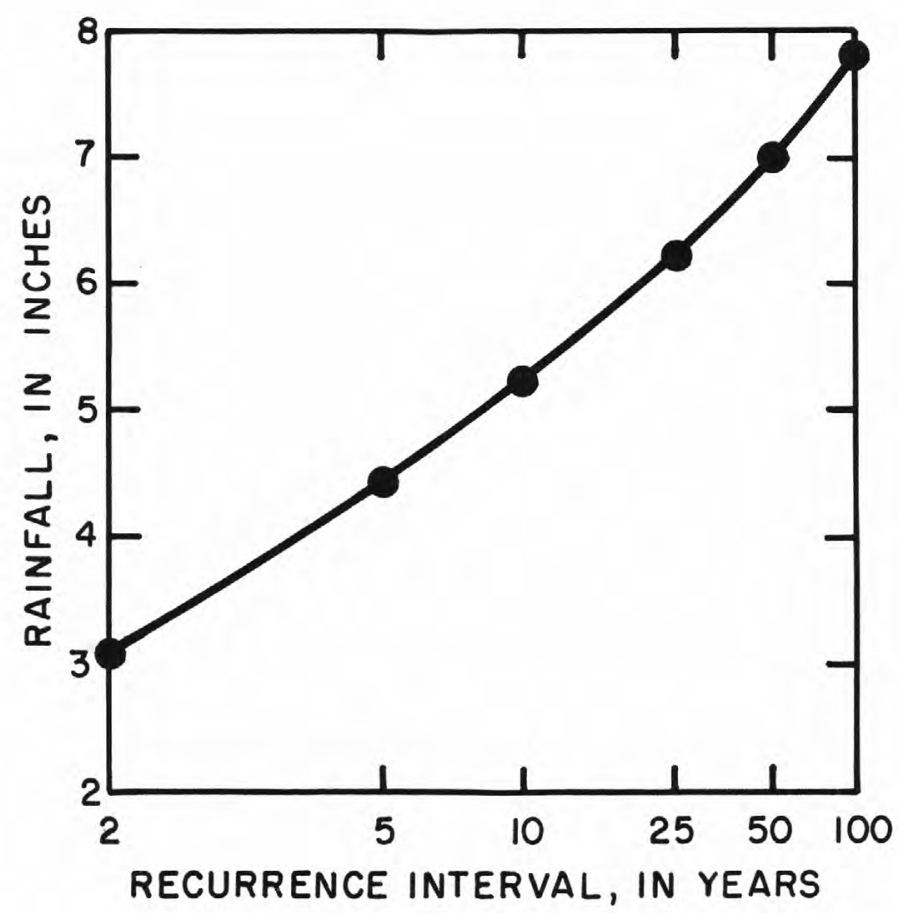

Figure 4.--24-hour rainfall frequency for the Wichita area, modified from Hershfleld (1961).

\section{Calculation of Synthetic Hydrograph}

The parameters that need to be known for a given basin are: (1) length of main channel, (2) slope of channel, (3) drainage area, (4) percentage of impervious surface, (5) hydrologic soll groups, and (6) land use. Length of main channel, slope of channel, and dralnage area can be determined from topographic maps supplemented with information on the storm-sewer system. The percentage of impervious surface can be measured using aerlal photos, or a percentage can be based on the expected future degree of urbanization. The hydrologic soil group for a basin in Wichita (based on data from Penner, 1978) can be determined from figure 5. The soll typing, as used here, is divided into four categorles according to infiltration capacity. Type A is a predominantly sandy texture with a high infiltration capacity; type D is a heavy soil with a high clay content and low infiltration capacity. Types $B$ and $C$ have intermediate infiltration capacities.

Using information on land use in the basin combined with the hydrologic soll group, the curve number (CN) can be determined from table 4. The curve numbers in table 4 are based on the average antecedent moisture condition (condition 11), which is the condition assumed for the probability-discharge calculation. The numbered curve determined from table 4 is used in estimating the runoff resulting from a given amount of rainfall, as shown in figure 6 . 


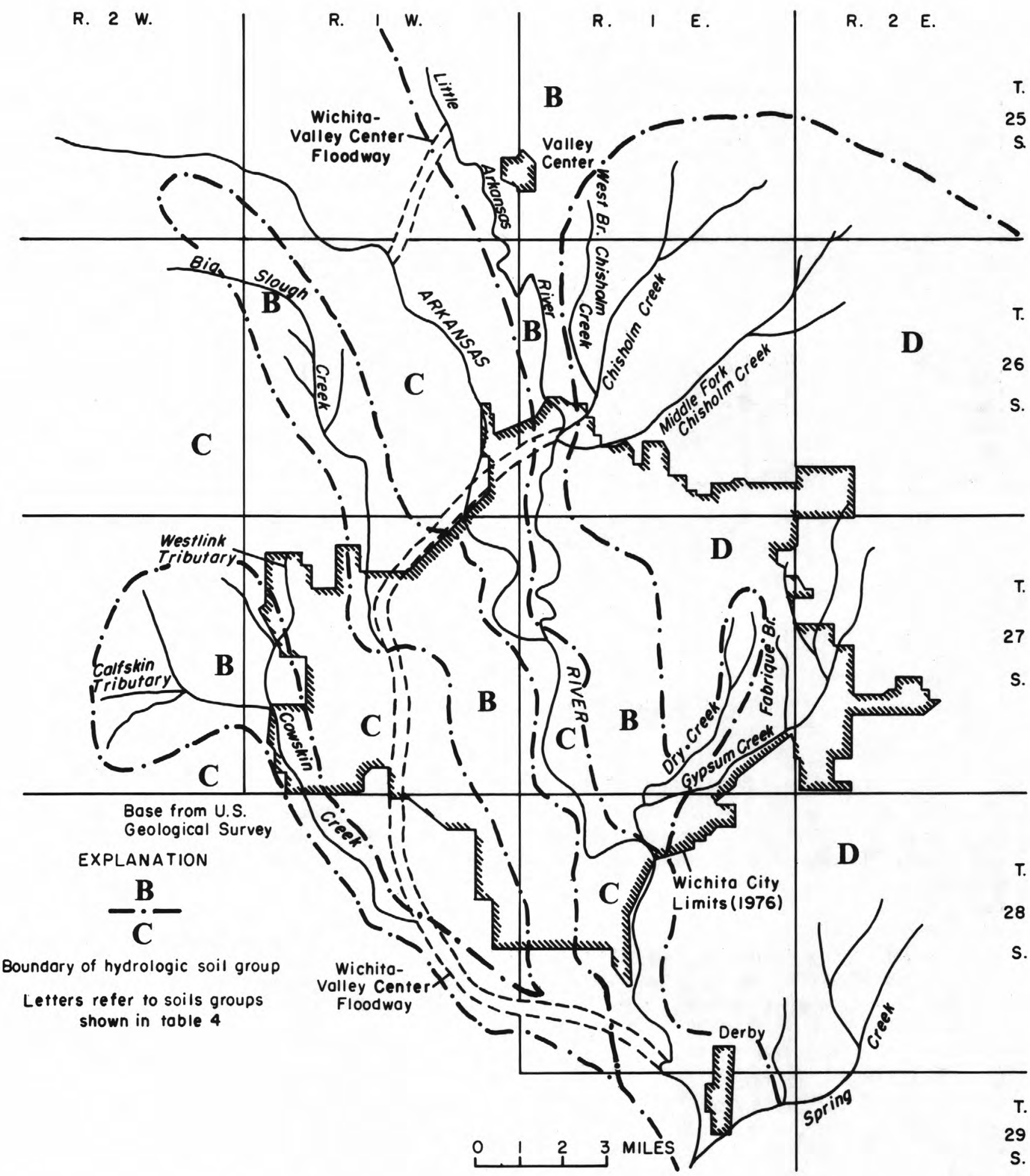

Figure 5.--Soll classification according to infiltration capacity. 
Table 4.--Runoff curve numbers for selected agricultural, suburban, and urban land use. (Antecedent moisture condition II).

[From SCS Tech. Release No. 55 (1975)]

\begin{tabular}{|c|c|c|c|c|}
\hline \multirow{2}{*}{ LAND USE DESCRIPTION } & \multicolumn{4}{|c|}{ HYDROLOGIC SOIL GROUP } \\
\hline & A & B & $\mathrm{C}$ & D \\
\hline $\begin{aligned} \text { Cultivated land: without conservation treatment } \\
: \text { with conservation treatment }\end{aligned}$ & $\begin{array}{l}72 \\
62\end{array}$ & $\begin{array}{l}81 \\
71\end{array}$ & $\begin{array}{l}88 \\
78\end{array}$ & $\begin{array}{l}91 \\
81\end{array}$ \\
\hline $\begin{array}{r}\text { Pasture or range land: poor condition } \\
: \text { good condition }\end{array}$ & $\begin{array}{l}68 \\
39\end{array}$ & $\begin{array}{l}79 \\
61\end{array}$ & $\begin{array}{l}86 \\
74\end{array}$ & $\begin{array}{l}89 \\
80\end{array}$ \\
\hline Meadow: good condition & 30 & 58 & 71 & 78 \\
\hline $\begin{aligned} \text { Wood or Forest land: thin stand, poor cover, no mulch } \\
\text { : good cover }\end{aligned}$ & $\begin{array}{l}45 \\
25\end{array}$ & $\begin{array}{l}66 \\
55\end{array}$ & $\begin{array}{l}77 \\
70\end{array}$ & $\begin{array}{l}83 \\
77\end{array}$ \\
\hline $\begin{array}{l}\text { Open Spaces, lawns, parks, golf courses, cemeterles, } \\
\text { etc. } \\
\begin{aligned} \text { good condition: } & \text { grass cover on } 75 \% \text { or more of } \\
\text { the area } & \\
\text { fair condition: } & \begin{array}{l}\text { grass cover on } 50 \% \text { to } 75 \% \text { of } \\
\text { the area }\end{array}\end{aligned}\end{array}$ & 49 & 61 & 74 & $\begin{array}{l}80 \\
84\end{array}$ \\
\hline Commercial and business areas ( $85 \%$ impervious) & 89 & 92 & 94 & 95 \\
\hline Industrial districts ( $72 \%$ impervious) & 81 & 88 & 91 & 93 \\
\hline $\begin{array}{ll}\text { Residential:* } & \\
\text { Average lot size } & \text { Average } \% \text { impervious** } \\
1 / 8 \text { acre or less } & 65 \\
1 / 4 \text { acre } & 38 \\
1 / 3 \text { acre } & 30 \\
1 / 2 \text { acre } & 25 \\
1 \text { acre } & 20\end{array}$ & $\begin{array}{l}77 \\
61 \\
57 \\
54 \\
51\end{array}$ & $\begin{array}{l}85 \\
75 \\
72 \\
70 \\
68\end{array}$ & $\begin{array}{l}90 \\
83 \\
81 \\
80 \\
79\end{array}$ & $\begin{array}{l}92 \\
87 \\
86 \\
85 \\
84\end{array}$ \\
\hline Paved parking lots, roofs, driveways, etc. & 98 & 98 & 98 & 98 \\
\hline $\begin{aligned} & \text { Streets and roads: } \text { paved with curbs and storm sewers } \\
& \text { gravel } \\
& \text { dirt }\end{aligned}$ & $\begin{array}{l}98 \\
76 \\
72\end{array}$ & $\begin{array}{l}98 \\
85 \\
82\end{array}$ & $\begin{array}{l}98 \\
89 \\
87\end{array}$ & $\begin{array}{l}98 \\
91 \\
89\end{array}$ \\
\hline
\end{tabular}

* Curve numbers are computed assuming the runoff from the house and driveway is directed towards the street with a minimum of roof water directed to lawns, where additional infiltration could occur.

* The remaining pervious areas (lawn) are considered to be in good pasture condition. 


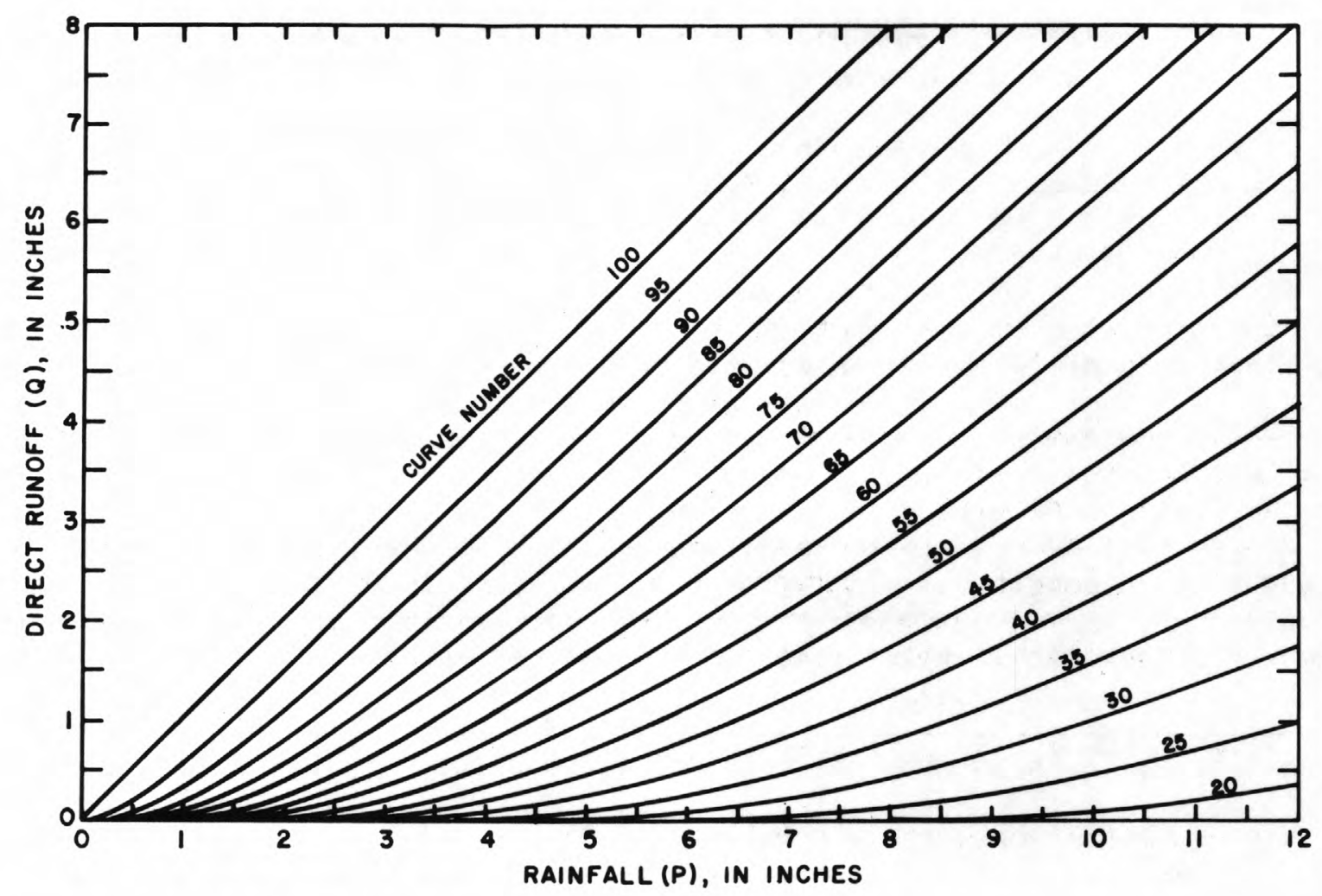

Figure 6.--Relationship of runoff to rainfall and curve number (from Mockus, 1955).

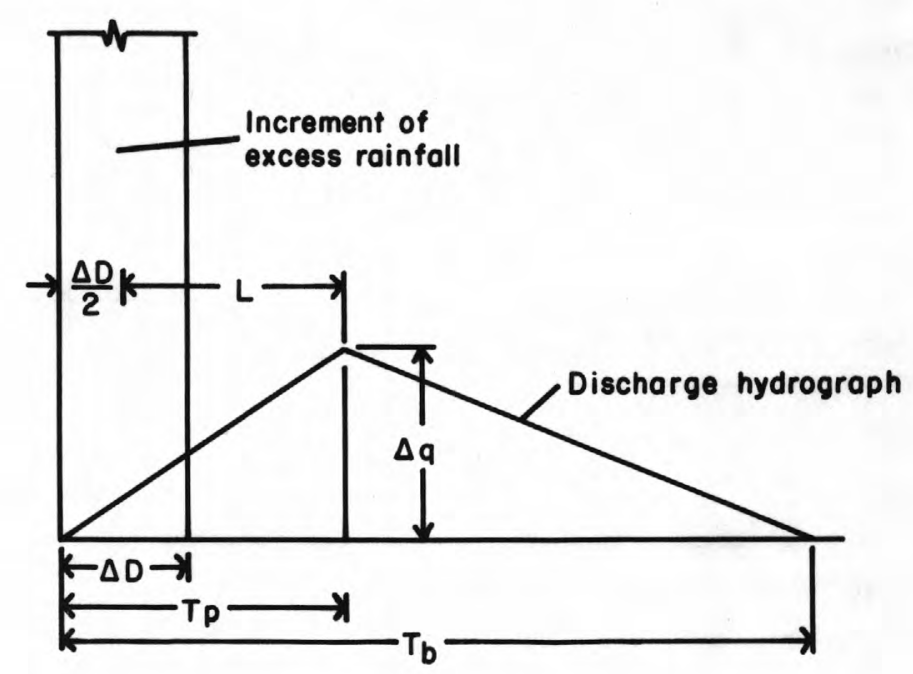

Figure 7.--Trlangular hydrograph relationships. 
The adjustment for lag time is determined by the equation (Putnam, 1972):

$$
L=0.49\left[\frac{l}{\sqrt{S}}\right]^{0.5}(1)^{-0.57},
$$

where $L=$ lag time, in hours

$\ell=$ length of main water course, in miles

$S=$ channel slope, in feet per mile

1 = ratio of impervious area to total drainage area

(Even though Putnam's definition of lag time differs slightly from that of the SCS, numerical results from the quoted equation were found to be compatible with the SCS procedure).

A synthetic hydrograph for each increment of rainfall can be developed by the use of a triangular hydrograph, as lllustrated in figure 7. The first step considers the relationship between the varlables in figure 7 . Examination of many hydrographs has shown that the average relation is

$$
\text { ( Time of base) } T_{b}=2.67\left(\frac{\Delta D}{2}+L\right) \text {, and }
$$

from the geometry in figure 7 it follows that:

$$
\Delta q=\frac{484 A(\Delta Q)}{\frac{\Delta D}{2}+L},
$$

where $\Delta D=$ time increment, in hours

$\Delta q=$ peak discharge, in cubic feet per second for an increment of runoff

$\Delta Q=$ runoff, in inches during period $\Delta D$

$A=$ drainage area, in square miles

$L=$ lag time, in hours;

and 484 is a constant that includes conversion of units.

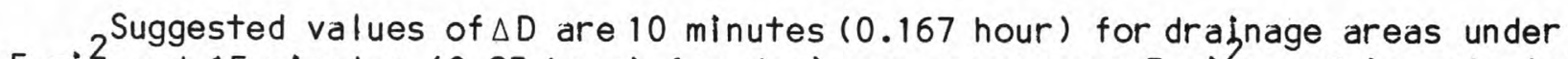
$5 \mathrm{mi}^{2}$ and 15 minutes $\left(0.25\right.$ hour) for drainage areas over $5 \mathrm{mi}^{2}$. $\Delta Q$ is calculated from the cumulative $Q$, which is found by the use of figure 6 . 
In order to demonstrate the method used, a numerical example is shown for calculating the 100-year flood for a hypothetical urbanized basin in Wichita:

Given the following basin gharacteristics:

drainage area $(A)=8.9 \mathrm{mi}^{2}$,

$\triangle D$ of 0.25 hour is used for areas larger than $5 \mathrm{ml}^{2}$,

main-stream length $(l)=9.4$ miles,

channel slope $(S)=14 \mathrm{ft} / \mathrm{mile}$,

impervious area ratio $(I)=0.20$.

1. Determine the hydrologic soll group. For this basin, assume figure 5 shows group $C$.

2. Determine the percentage of basin area having each land use. Using table 4, calculate the weighted curve number (CN). The following table shows the calculations:

Land Use

Residential, $1 / 8$ acre

Commercial and business area

Streets, paved with curbs and sewers

Paved parking lots

Open spaces, lawns, parks, etc., good condition

Weighted $C N=\frac{8,540}{100}=85$.
Percent

30

15

10

5

40

Total
Product

2,700

1,410

980

490

$\underline{2,960}$

8,540

3. Calculate the lag time ( $L$ ) by Putnam's equation:

$$
\begin{aligned}
L & =0.49\left[\frac{l}{\sqrt{S}}\right]^{0.5}(1)^{-0.57} \\
& =0.49\left[\frac{9.4}{\sqrt{14}}\right]^{0.5}(0.20)^{-0.57} \\
& =1.94 \text { hours. }
\end{aligned}
$$


4. Calculate the time to peak $\left(T_{p}\right)$ and time of base $\left(T_{b}\right)$ :

$$
\begin{aligned}
& T_{P}=\left(\frac{\Delta D}{2}+L\right)=\left(\frac{0.25}{2}\right)+1.94=2.06 \text { hours, } \\
& T_{b}=2.67 T_{P}=2.67(2.06)=5.51 \text { hours. }
\end{aligned}
$$

5. Calculate the numerical relationship between $\Delta q$ and $\Delta Q$ :

$$
\Delta q=\frac{484 A(\Delta Q)}{\frac{\Delta D}{2}+L} .
$$

Using 0.25 hour for $\Delta D$,

$$
\Delta q=\frac{484(8.9) \Delta Q}{0.125+1.94}=2090(\Delta Q)
$$

Similarly, when $\Delta D=0.50$ hour, the result is $\Delta q=1970(\Delta Q)$. when $\Delta D=1.00$ hour, the result is $\Delta q=1770(\Delta Q)$.

6. Figure 4 shows that the 100-year, 24-hour rainfall is 7.8 inches.

7. Using the results of steps 5 and 6 and figures 3 and 6 , prepare the results, as shown in table 5. The shortest time intervals are used during the time of most rapid accumulation of rainfall.

8. Using the $\Delta q$ values from table 5 and $T_{p}$ and $T_{p}$ previously calculated, plot the set of triangular hydrographs with their appropriate, respective starting times, as in figure 8 .

9. Construct the resulting synthetichydrograph by summing the ordinates of the triangular hydrographs. In figure 8, the triangular hydrograph ordinates were summed at each hour line. The resulting synthetic hydrograph has a peak of $7,400 \mathrm{ft}^{3} / \mathrm{s}$. 
Table 5.--Rainfall accumulation and triangular-hydrograph ordinates for 100-year storm.

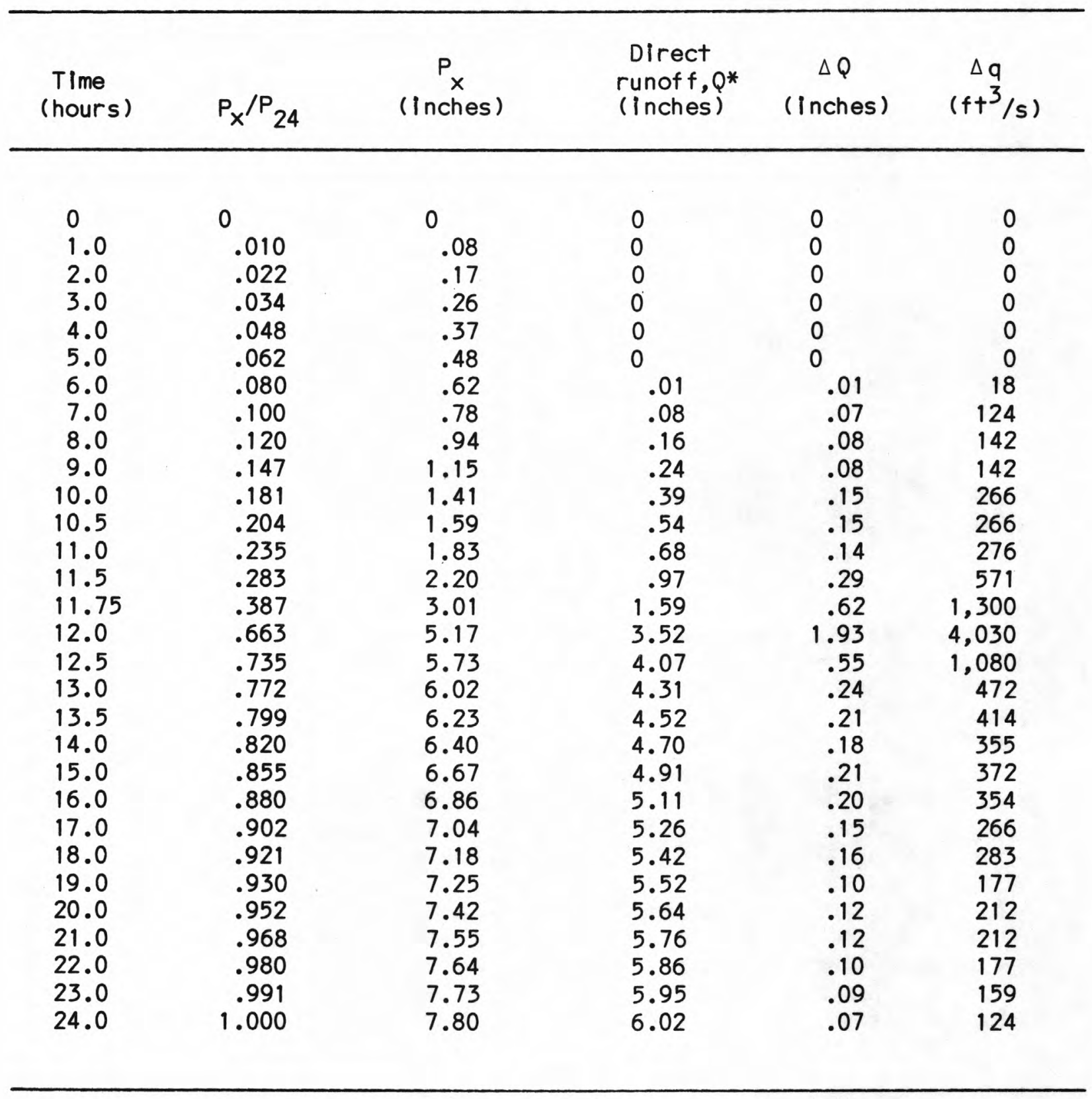

* Using curve number of 85 from step 3. 


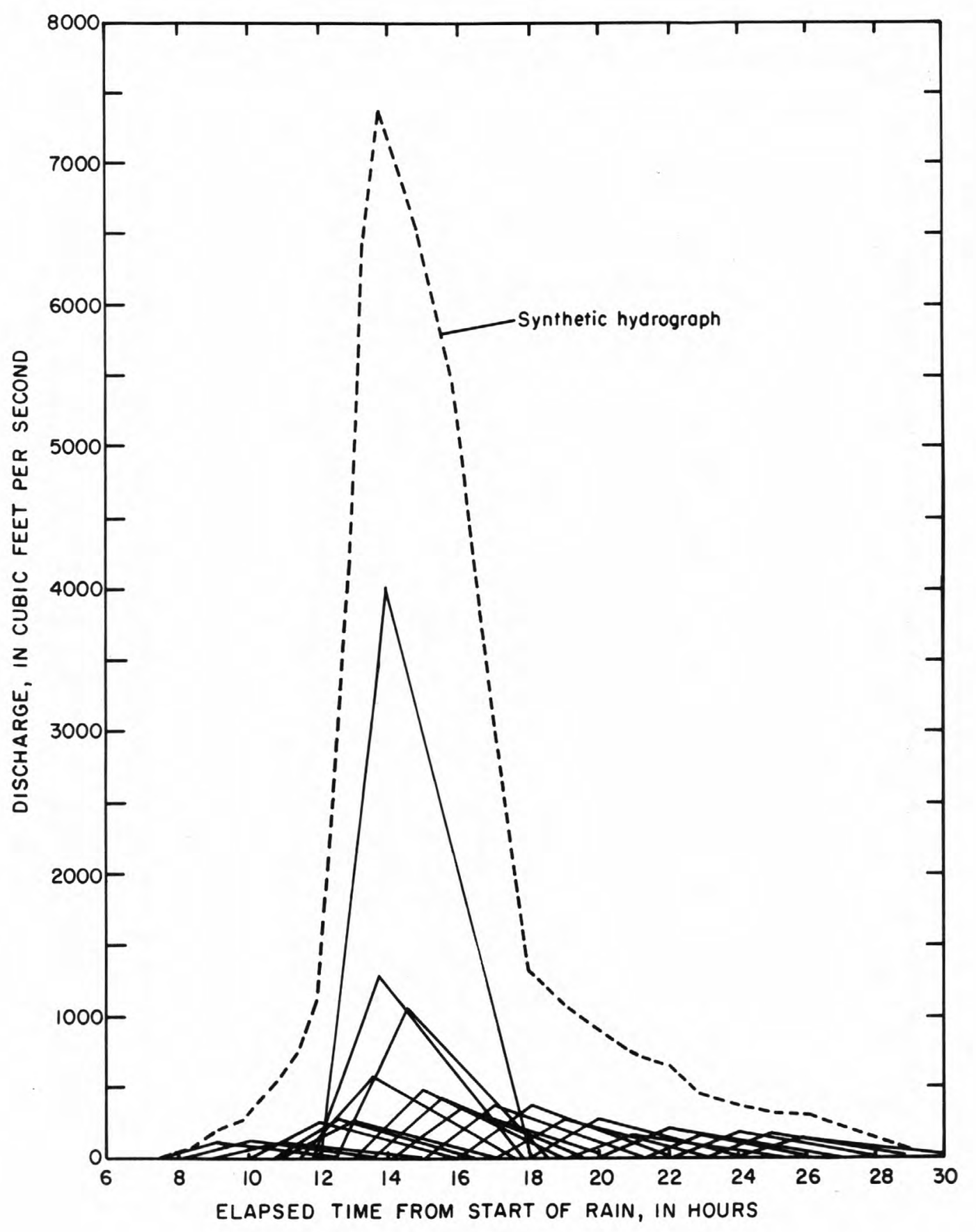

Figure 8.---Trlangular hydrographs and synthetic hydrograph resulting from 100year storm on hypothetical urbanized basin. 
The plotting of trlangular hydrographs and construction of the synthetic hydrograph are not necessary if only the peak discharge, rather than the complete hydrograph, is needed for a "design storm" having the proportional accumulation shown in figure 3. Kent (1973, p. 12-17) developed a shortcut solution using only the perlod of excess rainfall that directly affects the peak discharge. $A$ relationship between $\Delta D$ and $L$ can be chosen that enables the summation of only a single ordinate from each trlangular hydrograph, which can be calculated rather than plotted. The usual choice is to make $\Delta D$ equal to one-third the time to peak $\left(T_{p}\right)$, which is equivalent to choosing $\Delta D$ equal to $0.4 \mathrm{~L}$. For the ralnfall accumulation shown in figure 3 and high curve numbers approprlate for urbanized areas, the effective peak-producing runoff perlod is $7 \Delta D$, and the midpoint of the most intense Increment of runoff is 11.88 hours, which is the midpoint of the fifth increment of the seven (Kent, 1973, p. 13-14).

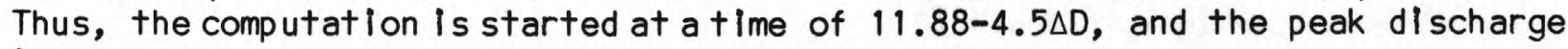
is:

$$
\begin{aligned}
q & =0.2 \Delta q_{1},+0.4 \Delta q_{2}+0.6 \Delta q_{3}+0.8 \Delta q_{4} \\
& +1.0 \Delta q_{5}+\frac{2}{3} \Delta q_{6}+\frac{1}{3} \Delta q_{7},
\end{aligned}
$$

In which $q$ is the peak discharge, and $\Delta q_{1}, \Delta q_{2}$, etc. are the peaks of the triangular hydrographs for the first through the seventh perlods of the seven used.

In the case of the hypothetical basin used in the previous numerical example, $L$ is 1.94 hours, so

$$
\Delta D=0.4(1.94)=0.78 \text { hour. }
$$

The starting time is

$$
11.88-4.5(0.78)=8.37 \text { hours. }
$$

For $\Delta D=0.78$ hour, $A=8.9 \mathrm{mi}^{2}$, and $L=1.94$ hours, the relation between $\Delta \mathrm{q}$ and $\Delta Q$ is

$$
\Delta q=\frac{484 .(8.9) \Delta Q}{\frac{0.78}{2}+1.94}=1,850 \Delta Q .
$$

Using figure 3 , the seven required $\Delta q$ values can be calculated as shown in table 6 . 
Table 6.--Calculation of $\Delta q$ for seven increments.

\begin{tabular}{|c|c|c|c|c|c|c|}
\hline Increment & $\begin{array}{l}\text { Time, } \\
\text { hours }\end{array}$ & $P_{x} / P_{24}$ & $\underset{x}{P_{x}}$ & $\begin{array}{l}\text { Direct } \\
\text { runof } f, Q \\
\text { (inches) }\end{array}$ & $\begin{array}{c}\Delta Q \\
\text { (inches) }\end{array}$ & $\left(f+\frac{\Delta}{3} q / s\right)$ \\
\hline & 8.37 & 0.130 & 1.01 & 0.19 & & \\
\hline 1 & 9.15 & .150 & 1.17 & .21 & 0.02 & 37 \\
\hline 2 & 9.93 & .178 & 1.39 & .38 & .17 & 314 \\
\hline 3 & 10.71 & .217 & 1.69 & .60 & .22 & 407 \\
\hline $\begin{array}{l}4 \\
5\end{array}$ & 11.49 & .290 & 2.26 & .95 & $\begin{array}{r}.35 \\
2.87\end{array}$ & $\begin{array}{r}647 \\
5,310\end{array}$ \\
\hline 6 & 12.27 & .730 & 5.69 & 3.82 & .52 & 961 \\
\hline 7 & $\begin{array}{l}13.05 \\
13.83\end{array}$ & $\begin{array}{l}.775 \\
.815\end{array}$ & 6.04 & $\begin{array}{l}4.34 \\
4.61\end{array}$ & .27 & 499 \\
\hline
\end{tabular}

The peak discharge is calculated by summing the appropriate fractions of the $\Delta q$ as follows:

$$
\begin{aligned}
q & =0.2(37)+0.4(314)+0.6(407)+0.8(647)+1.0(5,310) \\
& +0.67(961)+0.33(499) \\
& =7,000 \mathrm{ft}^{3} / \mathrm{s} .
\end{aligned}
$$

In the triangular- hydrograph solution the discharge was $7,400 \mathrm{ft}^{3} / \mathrm{s}$, which is a 5-percent difference. Other examples yielded similar results; thus, the shortcut calculation is sufficiently accurate for practical use.

\section{CONCLUSIONS}

Data collected in and near wich ita from 1964 through 1976 have provided a basis for testing the validity of the Soil Conservation Service synthetichydrograph method of computing flood hydrographs from rainfall data for small streams in the Wich ita urban area. Because the magnitude of intense storms was below normal in the 1964-76 period, only the largest storms for which adequate data were available were used for tests of the computation technique. The tests showed a need for modification in the calculations of lagtime, which was accomplished by using Putnam's (1972) equation. With the modification, the SCS method was found to be applicable to basins varying from slightly urbanized to fully urbanized in the Wichita area. Tests indicate the synthetic-hydrograph method may give slightly biased results; however, uncertainties in some of the data render impractical any adjustment for blas. 
Application of the modifled SCS method is fairly simple and requires data on Impervlous surface, solls, land use, channel slope, length of maln channel, drainage area, and rainfall in short increments of time for the selected storm. As an alternative to more complete and complex modeling by digital computer, a peak discharge for drainage design can be calculated by applying the modified SCS method to a standardized "design storm" for a specified recurrence interval.

The SCS method is sensitive to soll conditions and land use; therefore, accurate information on these factors is necessary. Continued and improved collection of data may provide for adjustment to remove the small blas from the method and also may provide adequate data for the future use of digital-computer models.

\section{REFERENCES}

Alley, W. M., 1977, Guide for collection, analysis, and use of urban stormwater data: American Society of Civil Engineers Conference Report, $115 \mathrm{p}$.

Anderson, D. G., 1970, Effects of urban development on floods in northern Virginla: U.S. Geological Survey Water-Supply Paper 2001-C, 22 p.

Dalrymple, Tate, 1960, Flood-frequency analyses: U.S. Geological Survey WaterSupply Paper 1543-A, 80 p.

Dempster, G. R., Jr., 1974, Effects of urbanization on floods in the Dallas, Texas metropolitan area: U.S. Geological Survey Water-Resources Investigations 60-73.

Ellis, D. W., and others, 1963, Floods at Wichita, Kansas: U.S. Geological Survey Hydrologic Investigations Atlas HA-63.

Espey, W. H., Jr., Morgan, C. W., and Masch, F. D., 1965, A study of some effects of urbanization on storm runoff from a small watershed: University of Texas, Technical Report HYD 07-6501, CRWR-2, 109 p.

Hershfield, D. M., 1961, Rainfall frequency atlas of the United States: U.S. Weather Bureau Technical Paper 40,115 p.

James, I. C., II, 1967, Flood runoff from partially urbanized areas, Wichita, Kansas, report number 1, analysis of initial conditions: U.S. Geological Survey Open-File Report, 62 p.

Johnson, S. L., and Sayre, D. M., 1973, Effects of urbanization on floods in the Houston, Texas metropollitan area: U.S. Geological Survey Water-Resources Investigations $3-73,50 \mathrm{p}$.

Jordan, P. R., and Irza, T. J., 1975, Magnitude and frequency of floods in Kansas, unregulated streams: Kansas Water Resources Board Technical Report $11,34 \mathrm{p}$.

Kent, K. M., 1973, A method of estimating volume and rate of runoff in small water sheds: U.S. Soll Conservation Service TP-149, 61 p.

Mawson, K. J., 1959, Varlation of runoff coefficient: New Zealand Engineer, v. 14, no. 11, p. 381-388.

Mockus, V., 1955, Estimating direct runoff amounts from storm rainfall: U.S. Soll Conservation Service, Central Technical Unit.

Penner, H., 1978, Soll survey of Sedgwick County, Kansas: U.S. Soll Conservation Service.

Putnam, A.L., 1972, Effect of urban development on floods in the Pledmont Province of North Carollina: U.S. Geological Survey Open-FIle Report, 87 p. 
U.S. Soll Conservation Service, 1964, Hydrology, part I, watershed planning: Soll Conservation Service National Engineer ing Handbook, Section 4, (NEH-4). 1975, Urban hydrology for small watersheds: Soll Conservation Service Technical Release No. 55, 74 p.

Wasson, B. E., 1969, Floods of July 2, 1968, in Jackson, Mississippl: U.S. Geological Survey Open-File Report, $10 \mathrm{p}$.

Wilson, K. V., 1968, Floods of June 1, 1967, in southwestern Jackson, Mississippi: U.S. Geological Survey Open-File Report, 22 p. 
APPENDIX

Rainfall and discharge data for selected storms 
Station 07144320, Gypsum Creek at Gllbert Street

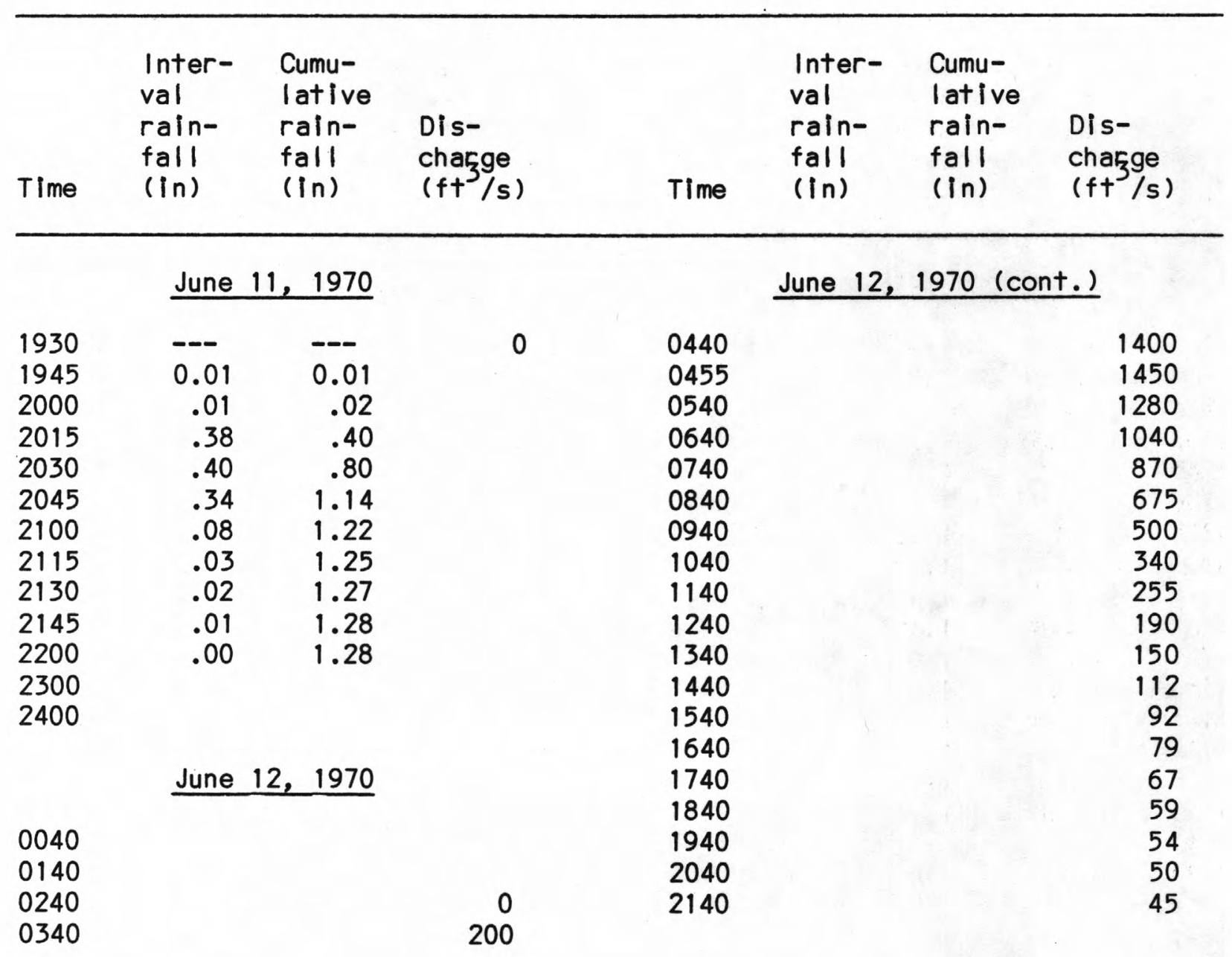


Station 07144320, Gypsum Creek at Gilbert Street (cont.)

\begin{tabular}{|c|c|c|c|c|c|c|c|}
\hline Time & $\begin{array}{l}\text { Inter- } \\
\text { val } \\
\text { rain- } \\
\text { fall } \\
\text { (in) }\end{array}$ & $\begin{array}{l}\text { Cumu- } \\
\text { lative } \\
\text { rain- } \\
\text { fall } \\
\text { (in) }\end{array}$ & $\begin{array}{l}\text { Dis- } \\
\text { charge } \\
\left(f t^{3} / s\right)\end{array}$ & Time & $\begin{array}{l}\text { Inter- } \\
\text { val } \\
\text { rain- } \\
\text { fall } \\
\text { (in) }\end{array}$ & $\begin{array}{l}\text { Cumu- } \\
\text { lative } \\
\text { rain- } \\
\text { fall } \\
\text { (in) }\end{array}$ & $\begin{array}{l}\text { Dis- } \\
\text { chargge } \\
\left(f+t^{3} / \mathrm{s}\right)\end{array}$ \\
\hline \multicolumn{4}{|c|}{ May 28; 1975} & \multicolumn{4}{|c|}{ May 28, 1975 (cont.) } \\
\hline 0045 & --- & -- & 0 & 1030 & & & 370 \\
\hline 0100 & 0.21 & 0.21 & & 1130 & & & 305 \\
\hline 0115 & .08 & .29 & & 1230 & & & 255 \\
\hline 0130 & .26 & .55 & 53 & 1330 & & & 222 \\
\hline 0145 & .46 & 1.01 & & 1430 & & & 200 \\
\hline 0200 & .20 & 1.21 & & 1530 & & & 177 \\
\hline 0215 & .01 & 1.22 & & 1630 & & & 165 \\
\hline 0230 & .09 & 1.31 & 710 & 1730 & & & 155 \\
\hline 0245 & .15 & 1.46 & & 1830 & & & 140 \\
\hline 0300 & .10 & 1.56 & & 1930 & & & 125 \\
\hline 0315 & .10 & 1.66 & & 2030 & & & 115 \\
\hline 0330 & .01 & 1.67 & 1100 & 2130 & & & 105 \\
\hline 0345 & .03 & 1.70 & & 2230 & & & 95 \\
\hline 0400 & .05 & 1.75 & & 2330 & & & 88 \\
\hline 0415 & .01 & 1.76 & & & & & \\
\hline 0430 & .00 & 1.76 & 1300 & \multicolumn{4}{|c|}{ May 29,1975} \\
\hline 0530 & & & 1150 & & & & \\
\hline 0630 & & & 1020 & 0030 & & & 81 \\
\hline 0730 & & & 820 & 0130 & & & 74 \\
\hline 0830 & & & 630 & 0230 & & & 62 \\
\hline 0930 & & & 485 & 0330 & & & 60 \\
\hline
\end{tabular}


Station 07144320, Gypsum Creek at Gilbert Street (cont.)

\begin{tabular}{|c|c|c|c|c|c|c|c|}
\hline Time & $\begin{array}{l}\text { Inter- } \\
\text { val } \\
\text { rain- } \\
\text { fall } \\
\text { (in) }\end{array}$ & $\begin{array}{l}\text { Cumu- } \\
\text { lative } \\
\text { rain- } \\
\text { fall } \\
\text { (in) }\end{array}$ & $\begin{array}{l}\text { Dis- } \\
\text { chargge } \\
\left(f+t^{\prime} / \mathrm{s}\right)\end{array}$ & Time & $\begin{array}{l}\text { Inter- } \\
\text { val } \\
\text { rain- } \\
\text { fall } \\
\text { (in) }\end{array}$ & $\begin{array}{l}\text { Cumu- } \\
\text { lative } \\
\text { rain- } \\
\text { fall } \\
\text { (in) }\end{array}$ & $\begin{array}{l}\text { Dis- } \\
\text { chargge } \\
\left(f+t^{3} / s\right)\end{array}$ \\
\hline \multicolumn{4}{|c|}{ June 2,1975} & \multicolumn{4}{|c|}{ June 3,1975 (cont.) } \\
\hline 2315 & -- & -- & & 0600 & & & 580 \\
\hline 2330 & 0.10 & 0.10 & 0 & 0700 & & & 400 \\
\hline 2345 & 1.02 & 1.12 & & 0800 & & & 310 \\
\hline \multirow[t]{4}{*}{2400} & .13 & 1.25 & 410 & 0900 & & & 255 \\
\hline & & & & 1000 & & & 203 \\
\hline & \multirow{2}{*}{\multicolumn{2}{|c|}{ June 3,1975}} & & 1100 & & & 172 \\
\hline & & & & 1200 & & & 145 \\
\hline 0015 & .14 & 1.39 & & 1300 & & & 132 \\
\hline 0030 & .15 & 1.54 & & 1400 & & & 120 \\
\hline 0045 & .05 & 1.59 & & 1500 & & & 103 \\
\hline 0100 & .04 & 1.63 & 870 & 1600 & & & 87 \\
\hline 0115 & .02 & 1.65 & & 1700 & & & 74 \\
\hline 0130 & .00 & 1.65 & & 1800 & & & 60 \\
\hline 0145 & .01 & 1.66 & & 1900 & & & 51 \\
\hline 0200 & .00 & 1.66 & 1100 & 2000 & & & 42 \\
\hline 0300 & & & 1250 & 2100 & & & 38 \\
\hline 0400 & & & 1070 & 2200 & & & 35 \\
\hline 0500 & & & 810 & & & & \\
\hline
\end{tabular}


Station 07144320, Gypsum Creek at Gilbert Street (concl.)

\begin{tabular}{|c|c|c|c|c|c|c|c|}
\hline Time & $\begin{array}{l}\text { Inter- } \\
\text { val } \\
\text { rain- } \\
\text { fall } \\
\text { (in) }\end{array}$ & $\begin{array}{l}\text { Cumu- } \\
\text { lative } \\
\text { rain- } \\
\text { fall } \\
\text { (in) }\end{array}$ & $\begin{array}{l}\text { Dis- } \\
\text { chasge } \\
(f+/ / s)\end{array}$ & Time & $\begin{array}{l}\text { Inter- } \\
\text { val } \\
\text { rain- } \\
\text { fall } \\
\text { (in) }\end{array}$ & $\begin{array}{l}\text { Cumu- } \\
\text { lative } \\
\text { rain- } \\
\text { fall } \\
(\text { in) }\end{array}$ & $\begin{array}{l}\text { Dis- } \\
\text { charge } \\
\left(f+\frac{f}{s}\right)\end{array}$ \\
\hline & \multicolumn{2}{|c|}{ June 16,1975} & & \multicolumn{4}{|c|}{ June 16,1975 (cont.) } \\
\hline 1800 & -- & -- & & 2330 & .00 & 1.88 & \\
\hline 1815 & 0.02 & 0.02 & & 2345 & .01 & 1.89 & \\
\hline 1830 & .01 & .03 & & 2400 & .01 & 1.90 & 940 \\
\hline 1845 & .00 & .03 & & & & & \\
\hline 1900 & .00 & .03 & & \multicolumn{4}{|c|}{ June 17,1975} \\
\hline 1915 & .00 & .03 & & & & & \\
\hline 1930 & .03 & .06 & & 0100 & .00 & 1.90 & 810 \\
\hline 1945 & .00 & .06 & & 0200 & & & 590 \\
\hline 2000 & .01 & .07 & 0 & 0300 & & & 400 \\
\hline 2015 & .51 & .58 & & 0400 & & & 308 \\
\hline 2030 & .21 & .79 & & 0500 & & & 260 \\
\hline 2045 & .06 & .85 & & 0600 & & & 212 \\
\hline 2100 & .00 & .85 & 200 & 0700 & & & 174 \\
\hline 2115 & .35 & 1.20 & & 0800 & & & 140 \\
\hline 2130 & .30 & 1.50 & & 0900 & & & 118 \\
\hline 2145 & .16 & 1.66 & & 1000 & & & 101 \\
\hline 2200 & .09 & 1.75 & 810 & 1100 & & & 88 \\
\hline 2215 & .03 & 1.78 & & 1200 & & & 74 \\
\hline 2230 & .03 & 1.81 & & 1300 & & & 62 \\
\hline 2245 & .02 & 1.83 & & 1400 & & & 52 \\
\hline 2300 & .03 & 1.86 & 1060 & 1500 & & & 45 \\
\hline 2315 & .02 & 1.88 & & 1600 & & & 39 \\
\hline
\end{tabular}


Station 07144323, Fabrique Branch of Gypsum Creek at Harry Street

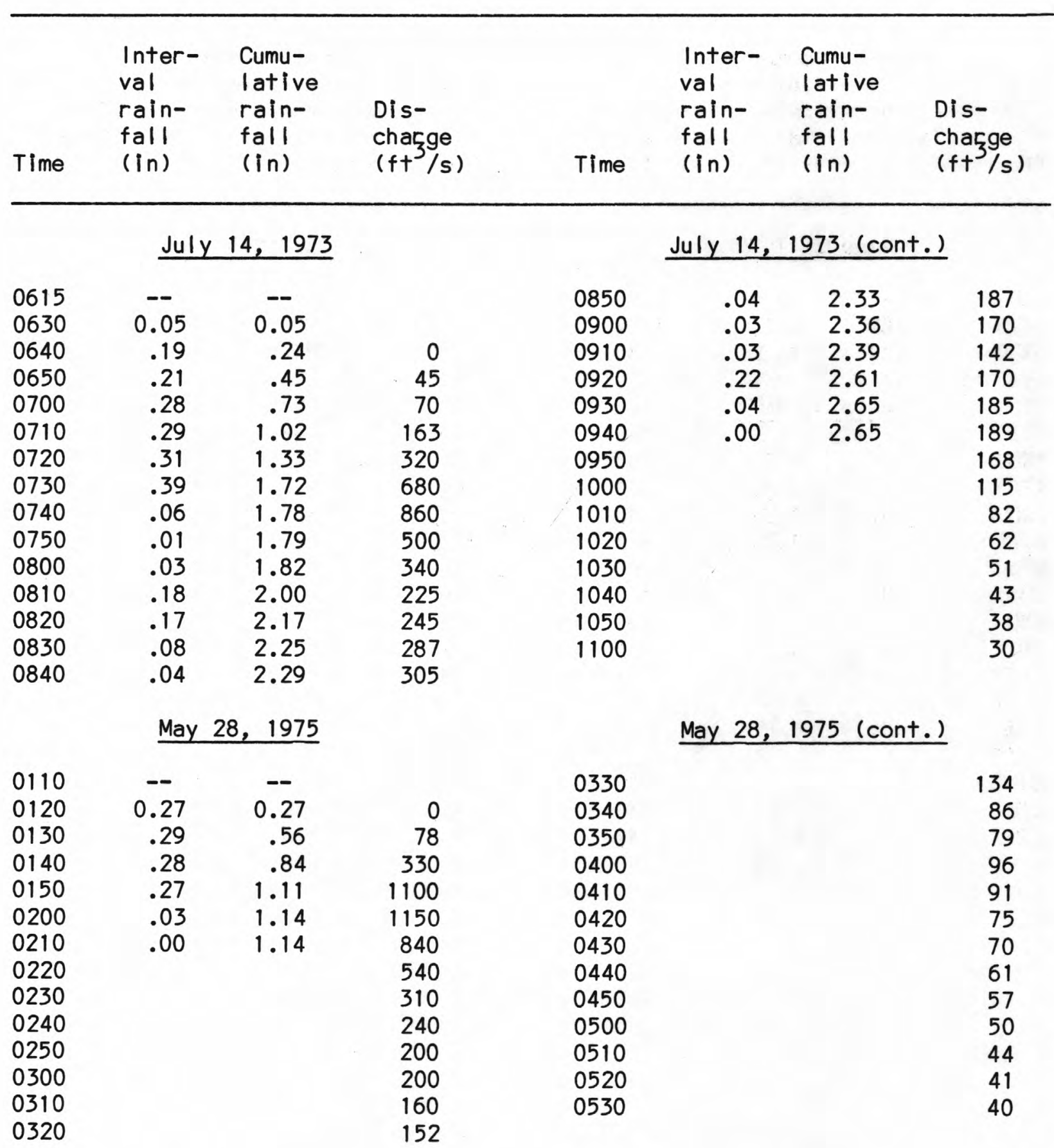


Station 07144323, Fabrique Branch of Gypsum Creek at Harry Street (concl.)

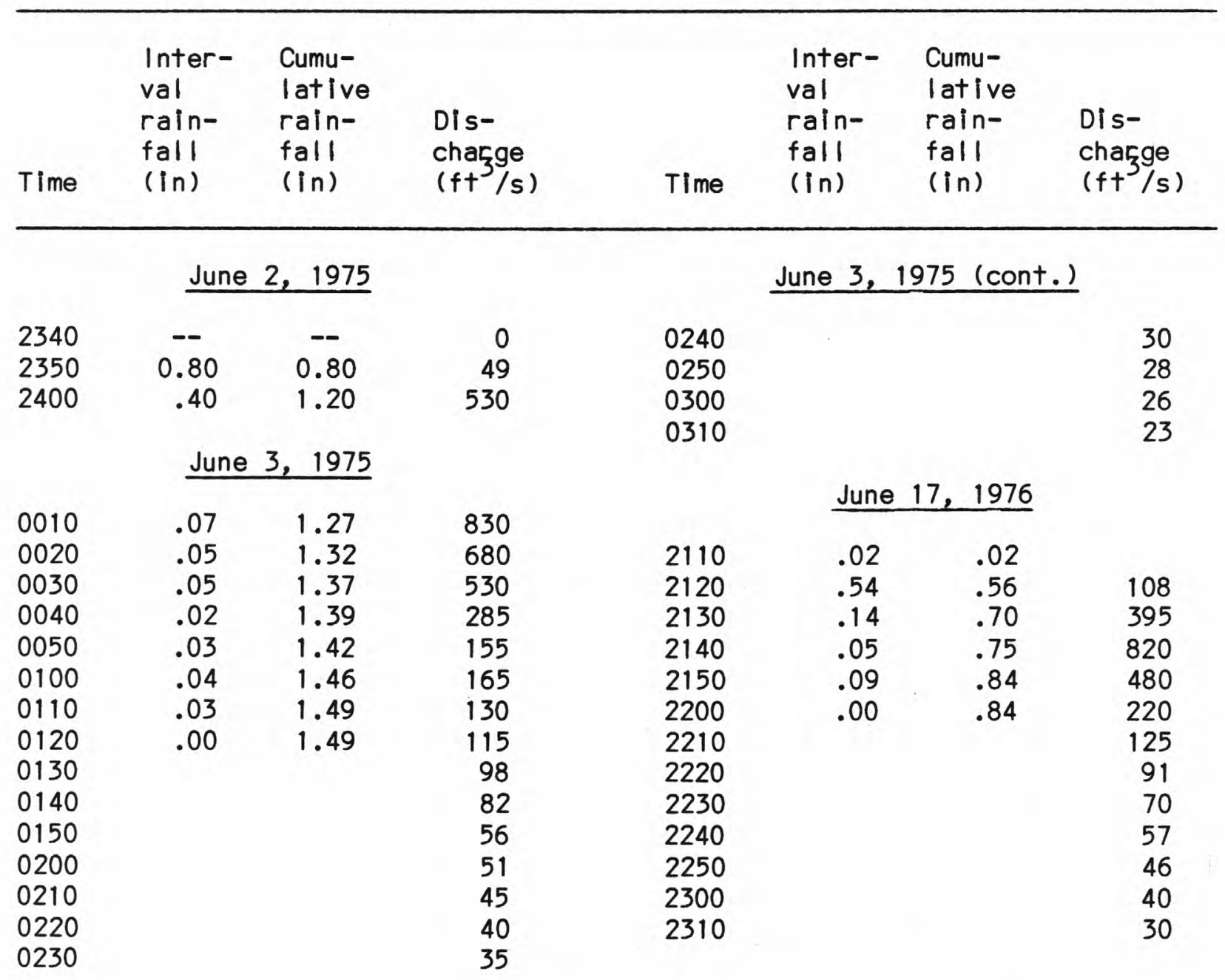


Station 07144325, Gypsum Creek at Oliver Street

\begin{tabular}{|c|c|c|c|c|c|c|c|}
\hline Time & $\begin{array}{l}\text { Inter- } \\
\text { val } \\
\text { rain- } \\
\text { fall } \\
\text { (in) }\end{array}$ & $\begin{array}{l}\text { Cumu- } \\
\text { lative } \\
\text { rain- } \\
\text { fall } \\
\text { (in) }\end{array}$ & $\begin{array}{l}\text { Dis- } \\
\text { charge } \\
(\mathrm{ft} / \mathrm{s})\end{array}$ & Time & $\begin{array}{l}\text { Inter- } \\
\text { val } \\
\text { rain- } \\
\text { fall } \\
\text { (in) }\end{array}$ & $\begin{array}{l}\text { Cumu- } \\
\text { lative } \\
\text { rain- } \\
\text { fall } \\
\text { (in) }\end{array}$ & $\begin{array}{l}\text { Dis- } \\
\text { chargge } \\
(f+/ s)\end{array}$ \\
\hline & \multicolumn{3}{|c|}{ April 20, 1974} & \multicolumn{4}{|c|}{ April 20, 1974 (cont.) } \\
\hline 0600 & -- & - & 0 & 1215 & .16 & 1.30 & \\
\hline 0615 & 0.01 & 0.01 & & 1230 & .20 & 1.50 & \\
\hline 0630 & .05 & .06 & & 1245 & .12 & 1.62 & \\
\hline 0645 & .07 & .13 & & 1300 & .07 & 1.69 & 1200 \\
\hline 0700 & .05 & .18 & 44 & 1315 & .01 & 1.70 & \\
\hline 0715 & .01 & .19 & & 1330 & .00 & 1.70 & \\
\hline 0730 & .00 & .19 & & 1400 & & & 1500 \\
\hline 0745 & .00 & .19 & & 1500 & & & 1550 \\
\hline 0800 & .01 & .20 & 57 & 1600 & & & 1470 \\
\hline 0815 & .01 & .21 & & 1700 & & & 1250 \\
\hline 0830 & .06 & .27 & & 1800 & & & 1020 \\
\hline 0845 & .02 & .29 & & 1900 & & & 650 \\
\hline 0900 & .04 & .33 & 76 & 2000 & & & 300 \\
\hline 0915 & .05 & .38 & & 2100 & & & 187 \\
\hline 0930 & .03 & .41 & & 2200 & & & 125 \\
\hline 0945 & .05 & .46 & & 2300 & & & 94 \\
\hline 1000 & .08 & .54 & 225 & 2400 & & & 75 \\
\hline 1015 & .09 & .63 & & & & & \\
\hline 1030 & .06 & .69 & & & April & 21,1974 & \\
\hline 1045 & .02 & .71 & & & & & \\
\hline 1100 & .01 & .72 & 550 & 0100 & & & 64 \\
\hline 1115 & .00 & .72 & & 0200 & & & 56 \\
\hline 1130 & .00 & .72 & & 0300 & & & 52 \\
\hline 1145 & .06 & .78 & & 0400 & & & 46 \\
\hline 1200 & .36 & 1.14 & 800 & 0500 & & & 42 \\
\hline
\end{tabular}


Station 07144325, Gypsum Creek at Oliver Street (cont.)

\begin{tabular}{|c|c|c|c|c|c|c|c|}
\hline Time & $\begin{array}{l}\text { Inter- } \\
\text { val } \\
\text { rain- } \\
\text { fall } \\
\text { (in) }\end{array}$ & $\begin{array}{l}\text { Cumu- } \\
\text { lative } \\
\text { rain- } \\
\text { fall } \\
\text { (in) }\end{array}$ & $\begin{array}{l}\text { Dis- } \\
\text { chasge } \\
\left(f t^{3} / \mathrm{s}\right)\end{array}$ & Time & $\begin{array}{l}\text { Inter- } \\
\text { val } \\
\text { rain- } \\
\text { fall } \\
\text { (in) }\end{array}$ & $\begin{array}{l}\text { Cumu- } \\
\text { lative } \\
\text { rain- } \\
\text { fall } \\
\text { (in) }\end{array}$ & $\begin{array}{l}\text { Dis- } \\
\text { chasgge } \\
\left(f t^{\prime} / s\right)\end{array}$ \\
\hline
\end{tabular}

May 9, 1974

0245

0315

0330

0345

0400

0415

0430

0445

0500

0515

0530

--
0.02
.01
.10
.04
.15
.12
.23
.04
.19
.06
.03

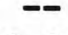

0.02

.03

.13

.17

.32

.44

.67

.71

.90

.96

.99

May 13,1974

2300
2315
2330
2345
2400

0015

0030

0045

0100

0110

$\begin{array}{rr}-- & -- \\ 0.11 & 0.11 \\ .09 & .20 \\ .35 & .55 \\ .47 & 1.02\end{array}$

May 14, 1974

$\begin{array}{ll}.15 & 1.17 \\ .04 & 1.21 \\ .00 & 1.21\end{array}$

May 9, 1974 (cont.)

0545

0600

0650

0700

0800

0900

1000

1100

1200

1300

1400

1500

$\begin{array}{ll}.15 & 1.14 \\ .23 & 1.37 \\ .00 & 1.37\end{array}$

665

1020

970

815

680

330

98

60

50

42

37

May 14, 1974 (cont.)

0200

0300

0400

0500

0600

0700

0800

0900

1000

1100

1200

1300

1400
800

770

550

305

115

86

65

55

48

42

39

32

30 
Station 07144325, Gypsum Creek at Olliver Street (concl.)

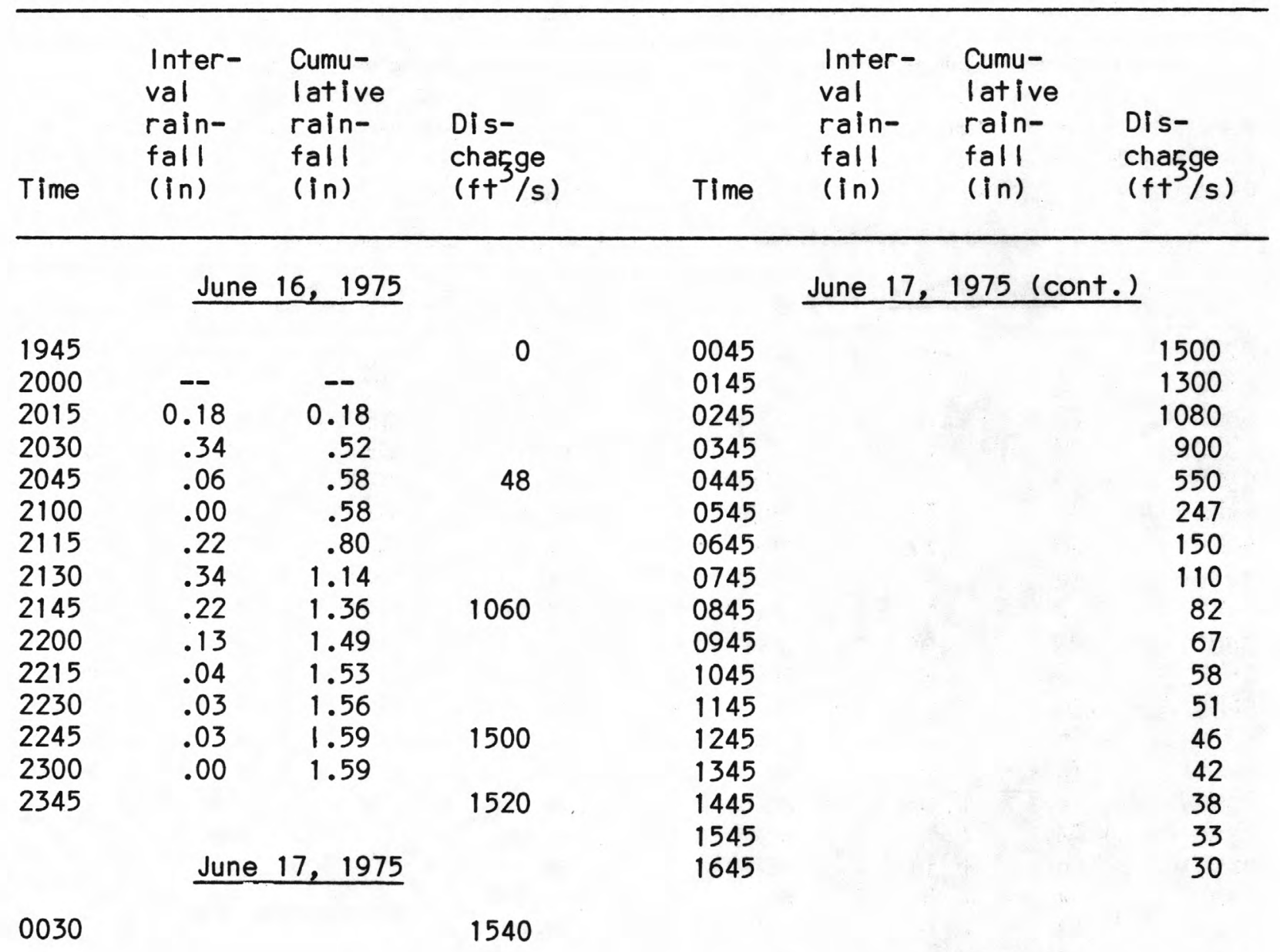


Station 07144330, Dry Creek at Lincoln Street

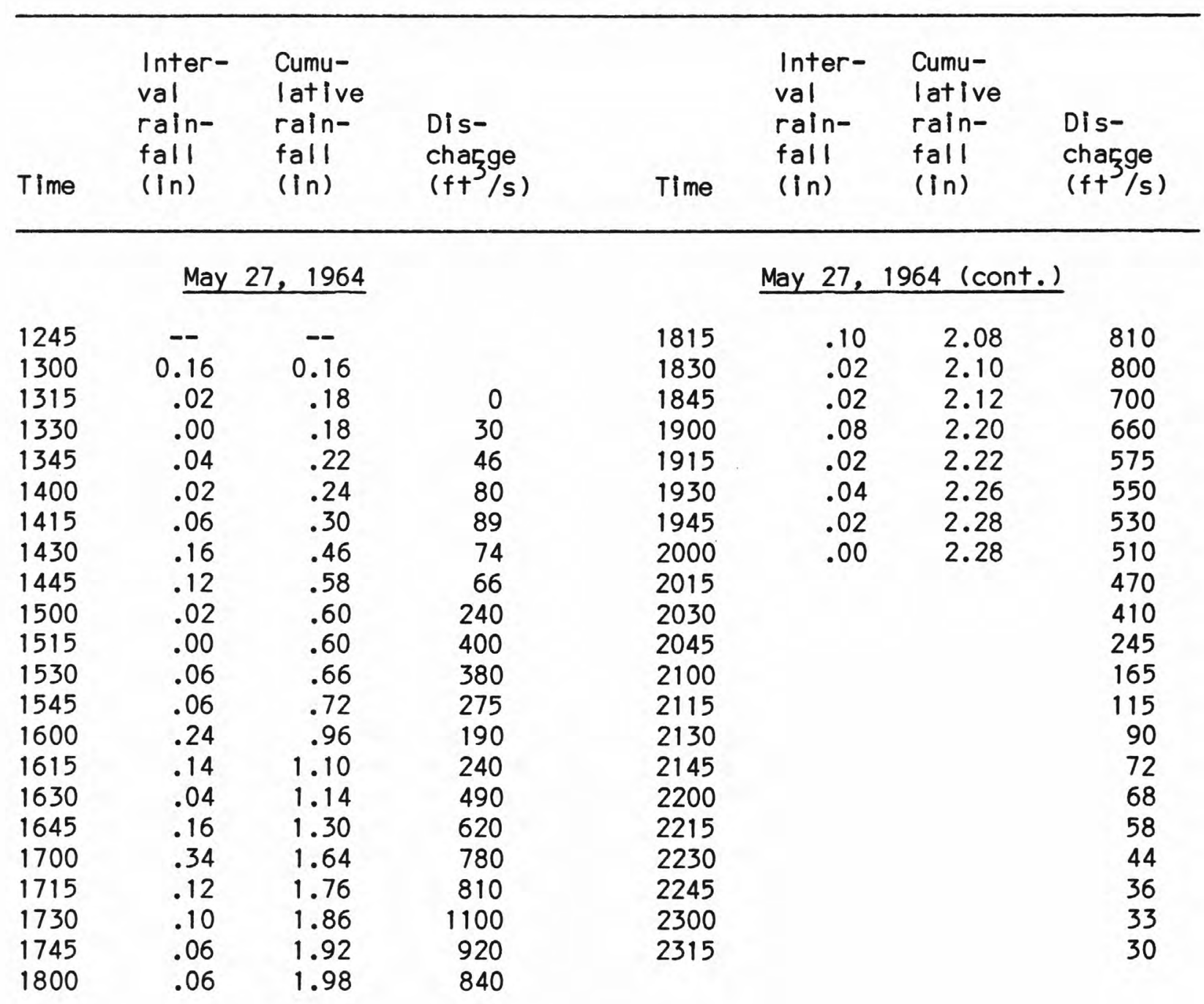


Station 07144330, Dry Creek at Lincoln Street (cont.)

\begin{tabular}{|c|c|c|c|c|c|c|c|}
\hline Time & $\begin{array}{l}\text { Inter- } \\
\text { val } \\
\text { rain- } \\
\text { fall } \\
\text { (in) }\end{array}$ & $\begin{array}{l}\text { Cumu- } \\
\text { lat ive } \\
\text { rain- } \\
\text { fall } \\
\text { (in) }\end{array}$ & $\begin{array}{l}\text { Dis- } \\
\text { charge } \\
\left(f t^{3} / \mathrm{s}\right)\end{array}$ & Time & $\begin{array}{l}\text { Inter- } \\
\text { val } \\
\text { rain- } \\
\text { fall } \\
\text { (in) }\end{array}$ & $\begin{array}{l}\text { Cumu- } \\
\text { lat ive } \\
\text { rain- } \\
\text { fall } \\
\text { (in) }\end{array}$ & $\begin{array}{l}\text { Dis- } \\
\text { chargge } \\
(f+/ s)\end{array}$ \\
\hline & \multicolumn{2}{|c|}{ June 4,1965} & & \multicolumn{4}{|c|}{ June 4,1965 (cont.) } \\
\hline 1330 & -- & -- & & 2200 & .08 & 3.14 & 490 \\
\hline 1345 & 0.44 & 0.44 & & 2215 & .08 & 3.22 & 810 \\
\hline 1400 & .06 & .50 & 0 & 2230 & .00 & 3.22 & 1100 \\
\hline 1415 & .00 & .50 & 60 & 2245 & .00 & 3.22 & 1170 \\
\hline 1430 & .08 & .58 & 118 & 2300 & .08 & 3.30 & 920 \\
\hline 1445 & .08 & .66 & 118 & 2315 & .04 & 3.34 & 740 \\
\hline 1500 & .02 & .68 & 118 & 2330 & .06 & 3.40 & 580 \\
\hline 1515 & .04 & .72 & 100 & 2345 & .04 & 3.44 & 490 \\
\hline 1530 & .02 & .74 & 104 & 2400 & .16 & 3.60 & 410 \\
\hline 1545 & .00 & .74 & 100 & & & & \\
\hline 1600 & .62 & 1.36 & 88 & \multirow{2}{*}{\multicolumn{4}{|c|}{ June 5,1978}} \\
\hline 1615 & .10 & 1.46 & 92 & & & & \\
\hline 1630 & .00 & 1.46 & 420 & 0015 & .10 & 3.70 & 395 \\
\hline 1645 & .00 & 1.46 & 575 & 0030 & .02 & 3.72 & 410 \\
\hline 1700 & .02 & 1.48 & 550 & 0045 & .04 & 3.76 & 450 \\
\hline 1715 & .00 & 1.48 & 430 & 0100 & .02 & 3.78 & 452 \\
\hline 1730 & .00 & 1.48 & 355 & 0115 & .02 & 3.80 & 410 \\
\hline 1745 & .02 & 1.50 & 355 & 0130 & .00 & 3.80 & 395 \\
\hline 1800 & .02 & 1.52 & 350 & 0145 & & & 340 \\
\hline 1815 & .04 & 1.56 & 280 & 0200 & & & 325 \\
\hline 1830 & .06 & 1.62 & 245 & 0215 & & & 260 \\
\hline 1845 & .02 & 1.64 & 240 & 0230 & & & 240 \\
\hline 1900 & .02 & 1.66 & 168 & 0245 & & & 190 \\
\hline 1915 & .00 & 1.66 & 150 & 0300 & & & 165 \\
\hline 1930 & .00 & 1.66 & 168 & 0315 & & & 110 \\
\hline 1945 & .00 & 1.66 & 150 & 0330 & & & 82 \\
\hline 2000 & .18 & 1.84 & 120 & 0345 & & & 63 \\
\hline 2015 & .00 & 1.84 & 100 & 0400 & & & 53 \\
\hline 2030 & .08 & 1.92 & 96 & 0415 & & & 44 \\
\hline 2045 & .02 & 1.94 & 125 & 0430 & & & 38 \\
\hline 2100 &.$\quad .00$ & 1.94 & 220 & 0445 & & & 34 \\
\hline 2115 & .28 & 2.22 & 245 & 0500 & & & 29 \\
\hline 2130 & .24 & 2.46 & 224 & 0515 & & & 26 \\
\hline 2145 & .60 & 3.06 & 280 & & & & \\
\hline
\end{tabular}


Station 07144330, Dry Creek at Lincoln Street (cont.)

\begin{tabular}{|c|c|c|c|c|c|c|c|}
\hline Time & $\begin{array}{l}\text { Inter- } \\
\text { val } \\
\text { rain- } \\
\text { fall } \\
\text { (in) }\end{array}$ & $\begin{array}{l}\text { Cumu- } \\
\text { lative } \\
\text { rain- } \\
\text { fall } \\
\text { (in) }\end{array}$ & $\begin{array}{l}\text { Dis- } \\
\text { chargge } \\
(f+3 / s)\end{array}$ & Time & $\begin{array}{l}\text { Inter- } \\
\text { val } \\
\text { rain- } \\
\text { fall } \\
\text { (in) }\end{array}$ & $\begin{array}{l}\text { Cumu- } \\
\text { lative } \\
\text { rain- } \\
\text { fall } \\
\text { (in) }\end{array}$ & $\begin{array}{l}\text { Dis- } \\
\text { chasge } \\
\left(f t^{3} / s\right)\end{array}$ \\
\hline
\end{tabular}

May 28, 1975

$\begin{array}{ll}0120 & -- \\ 0130 & 0.33 \\ 0140 & .47 \\ 0150 & .32 \\ 0200 & .12 \\ 0210 & .02 \\ 0220 & .00 \\ 0230 & .00 \\ 0240 & .14 \\ 0250 & .00 \\ 0300 & .01 \\ 0310 & .11 \\ 0320 & .03 \\ 0330 & .01 \\ 0340 & .00 \\ 0350 & \\ 0400 & \\ 0410 & \\ 0420 & \\ 0430 & \\ 0440 & \\ 0450 & \end{array}$

.-
0.33
.80
1.12
1.24
1.26
1.26
1.26
1.40
1.40
1.41
1.52
1.55
1.56
1.56

0

21

88

550

740

840

760

620

550

625

810

900

960

895

820

765

710

623

610

580

540

470
May 28, 1975 (cont.)

0500

0510

395

330

295

260

235

205

170

130

123

115

95

77

64

57

54

50

48

46

44

41

39 
Station 07144330, Dry Creek at Lincoln Street (concl.)

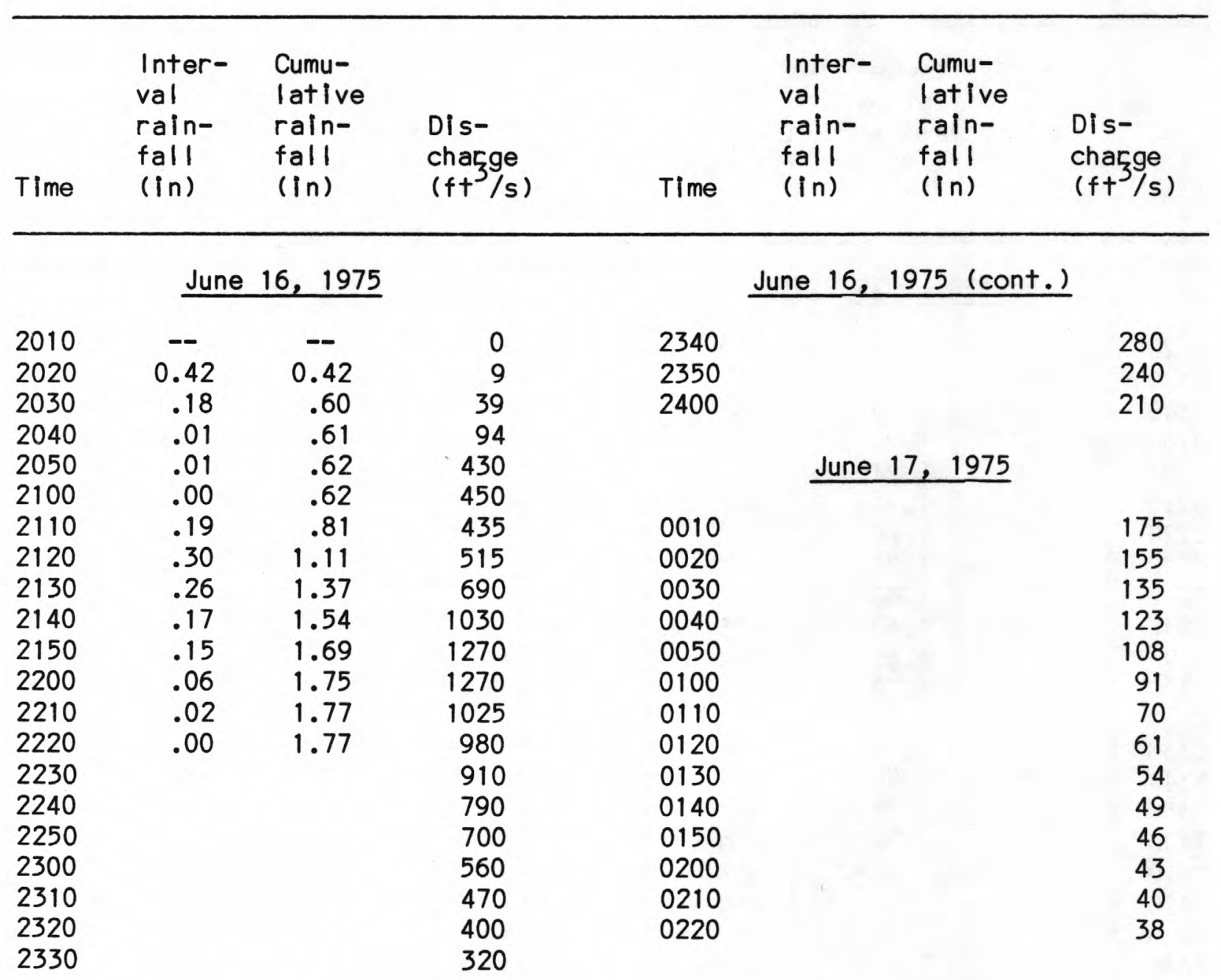


Station 0714340, Dry Creek at Pawnee Avenue

\begin{tabular}{|c|c|c|c|c|c|c|c|}
\hline Time & $\begin{array}{l}\text { Inter- } \\
\text { val } \\
\text { rain- } \\
\text { fall } \\
\text { (in) }\end{array}$ & $\begin{array}{l}\text { Cumu- } \\
\text { lative } \\
\text { rain- } \\
\text { fall } \\
\text { (in) }\end{array}$ & $\begin{array}{l}\text { Dis- } \\
\text { chasgge } \\
(f+3 / s)\end{array}$ & Time & $\begin{array}{l}\text { Inter- } \\
\text { val } \\
\text { rain- } \\
\text { fall } \\
\text { (in) }\end{array}$ & $\begin{array}{l}\text { Cumu- } \\
\text { lat ive } \\
\text { rain- } \\
\text { fall } \\
\text { (in) }\end{array}$ & $\begin{array}{l}\text { Dis- } \\
\text { chargge } \\
(f+3 / s)\end{array}$ \\
\hline
\end{tabular}

July 27,1971

$\begin{array}{lll}2230 & -- & -- \\ 2240 & 0.03 & 0.03 \\ 2250 & .07 & .10 \\ 2300 & .16 & .26 \\ 2310 & .42 & .68 \\ 2320 & .25 & .93 \\ 2330 & .10 & 1.03 \\ 2340 & .02 & 1.05 \\ 2350 & .00 & 1.05 \\ 2400 & .01 & 1.06 \\ & \text { July 28, } 1971\end{array}$

0010

0020

0030

0040

$\begin{array}{ll}.03 & 1.09 \\ .01 & 1.10 \\ .02 & 1.12 \\ .00 & 1.12\end{array}$

210

330

440

490

July 28, 1971 (cont.)

0050

0100

0110

0120

0130

0140

0150

0200

0210

0220

0230

0240

0250

0300

0310

0320

0330
520

500

450

392

340

293

250

208

187

164

145

114

92

73

56

44

37 
Station 07144340, Dry Creek at Pawnee Avenue (cont.)

\begin{tabular}{|c|c|c|c|c|c|c|c|}
\hline Time & $\begin{array}{l}\text { Inter- } \\
\text { val } \\
\text { rain- } \\
\text { fall } \\
\text { (in) }\end{array}$ & $\begin{array}{l}\text { Cumu- } \\
\text { lative } \\
\text { rain- } \\
\text { fall } \\
\text { (in) }\end{array}$ & $\begin{array}{l}\text { Dis- } \\
\text { charge } \\
(f+3 / s)\end{array}$ & Time & $\begin{array}{l}\text { Inter- } \\
\text { val } \\
\text { rain- } \\
\text { fall } \\
\text { (in) }\end{array}$ & $\begin{array}{l}\text { Cumu- } \\
\text { lative } \\
\text { rain- } \\
\text { fall } \\
\text { (in) }\end{array}$ & $\begin{array}{l}\text { Dis- } \\
\text { charge } \\
(f+3 / s)\end{array}$ \\
\hline \multicolumn{4}{|c|}{ June 16,1975} & \multicolumn{4}{|c|}{ July 17,1975} \\
\hline 2000 & -- & -- & & 0100 & & & 510 \\
\hline 2010 & 0.06 & 0.06 & & 0020 & & & 450 \\
\hline 2020 & .28 & .34 & & 0030 & & & 405 \\
\hline 2030 & .03 & .37 & & 0040 & & & 362 \\
\hline 2040 & .01 & .38 & & 0050 & & & 332 \\
\hline 2050 & .01 & .39 & & 0100 & & & 307 \\
\hline 2100 & .05 & .44 & 0 & 0110 & & & 280 \\
\hline 2110 & .54 & .98 & 10 & 0120 & & & 263 \\
\hline 2120 & .39 & 1.37 & 70 & 0130 & & & 240 \\
\hline 2130 & .41 & 1.78 & 103 & 0140 & & & 228 \\
\hline 2140 & .26 & 2.04 & 205 & 0150 & & & 215 \\
\hline 2150 & .12 & 2.16 & 313 & 0200 & & & 200 \\
\hline 2200 & .05 & 2.21 & 430 & 0210 & & & 180 \\
\hline 2210 & .02 & 2.23 & 600 & 0220 & & & 165 \\
\hline 2220 & .02 & 2.25 & 940 & 0230 & & & 145 \\
\hline 2230 & .02 & 2.27 & 1200 & 0240 & & & 130 \\
\hline 2240 & .02 & 2.29 & 1450 & 0250 & & & 112 \\
\hline 2250 & .01 & 2.30 & 1600 & 0300 & & & 96 \\
\hline 2300 & .00 & 2.30 & 1480 & 0310 & & & 80 \\
\hline 2310 & .01 & 2.31 & 1300 & 0320 & & & 67 \\
\hline 2320 & .01 & 2.32 & 1150 & 0330 & & & 52 \\
\hline 2330 & .01 & 2.33 & 980 & 0340 & & & 41 \\
\hline 2340 & .00 & 2.33 & 860 & 0350 & & & 30 \\
\hline 2350 & .01 & 2.34 & 760 & & & & \\
\hline 2400 & .00 & 2.34 & 590 & & & & \\
\hline
\end{tabular}


Station 07144340, Dry Creek at Pawnee Avenue (concl.)




Station 07144494, Westlink Tributary at Westfleld Avenue

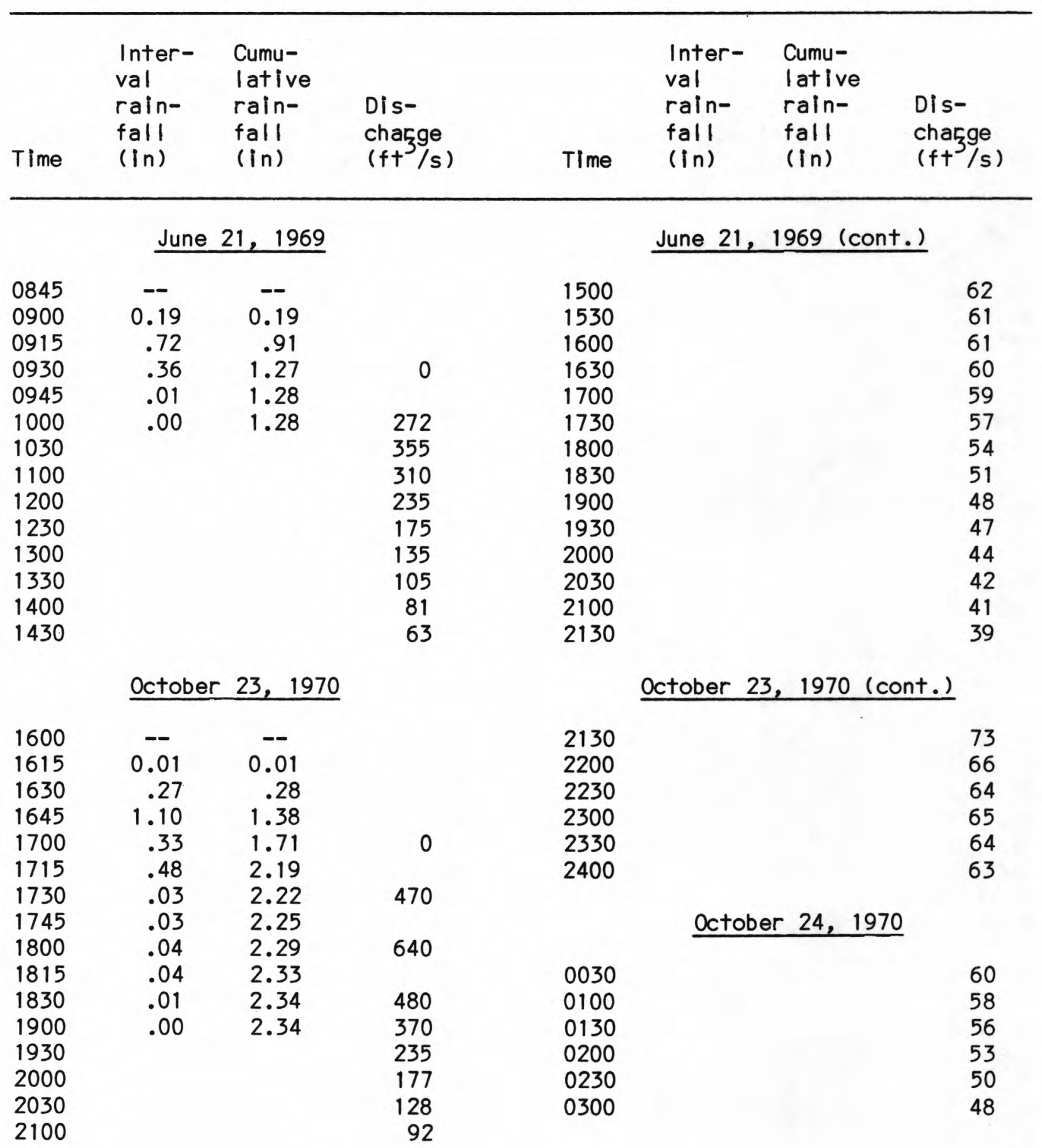


Station 07144494, Westlink Tributary at Westfleld Avenue (concl.)

\begin{tabular}{|c|c|c|c|c|c|c|c|}
\hline Time & $\begin{array}{l}\text { Inter- } \\
\text { val } \\
\text { rain- } \\
\text { fall } \\
\text { (in) }\end{array}$ & $\begin{array}{l}\text { Cumu- } \\
\text { lat Ive } \\
\text { rain- } \\
\text { fall } \\
\text { (in) }\end{array}$ & $\begin{array}{l}\text { Dis- } \\
\text { charge } \\
(\mathrm{ft} / \mathrm{s})\end{array}$ & Time & $\begin{array}{l}\text { Inter- } \\
\text { val } \\
\text { rain- } \\
\text { fall } \\
(\text { In) }\end{array}$ & $\begin{array}{l}\text { Cumu- } \\
\text { lat Ive } \\
\text { rain- } \\
\text { fall } \\
\text { (in) }\end{array}$ & $\begin{array}{l}\text { Dis- } \\
\text { chargge } \\
(f+/ s)\end{array}$ \\
\hline \multicolumn{4}{|c|}{ June 23,1976} & \multicolumn{4}{|c|}{ June 24,1976} \\
\hline 2200 & -- & -- & 0 & 0030 & & & 110 \\
\hline 2215 & 0.02 & 0.02 & & 0100 & & & 80 \\
\hline 2230 & .67 & .69 & 57 & 0130 & & & 59 \\
\hline 2245 & .45 & 1.14 & & 0200 & & & 46 \\
\hline 2300 & .01 & 1.15 & 195 & 0230 & & & 35 \\
\hline 2315 & .00 & 1.15 & & 0300 & & & 31 \\
\hline 2330 & .00 & 1.15 & 178 & 0330 & & & 28 \\
\hline 2345 & .06 & 1.21 & & & & & \\
\hline 2400 & .00 & 1.21 & 144 & & & & \\
\hline
\end{tabular}

\$U.S. GOVERNMENT PRINTING OFFICE: 1978--666257/215 
